\title{
Türkiye ve İran Çağdaş Mimarisi Dönüşümünde Ulusalcı Hareketlerin Etkisi
}

\author{
NAVID KHALEGHIMOGHADDAM \\ navid.khaleghi1363@gmail.com \\ ORCID ID: 0000-0003-2505-207X
}

Öz: Bu makale ilk olarak milliyetçiliğin 1920-1950 yılları arasında İran'da ve Türki-ye’de oluşturduğu toplumsal ve siyasi platformu inceleyerek, milliyetçi fikirlerin oluşumundaki temel faktörleri tanıtmaya çalışmaktadır. Yazar, İran ve Türkiye hükümetlerinin milliyetçiliği güçlendirme çabalarına odaklanıp aralarındaki resmi iş birliğinin milliyetçi hareketlerin oluşumunu nasıl etkilediğini incelemektedir. Araştırma, Türkiye ve İran'da bu milliyetçi politikaların sonucu olarak geliştirilen milliyetçi mimari hareketler ile ilgili tanıtımlar ortaya koymaktadır. Dolayısıyla, İran ve Türkiye mimarisi ile ilgili eleştirmenlerin görüşlerine dayanarak bu milli-yetçi mimari hareketleri ve iki ülkenin bazı mimari eserlerini incelemektedir. So-nunda, hükümet politikalarının İran ve Türkiye’de milliyetçi mimari hareketlerin ortaya çıkışını nasıl etkilediğini tartışmak üzere karşılaştırmalı bir çalışma yürü-tülmektedir. Bu karşılaştırmanın sonucuna göre 1920'lerin başından bu yana, İran ve Türkiye, yönetim biçimi ve halkın yaşam tarzında köklü değişiklikler talep etme konusundaki tecrübelerini yaşamaktadırlar ve bu yolda dini düşünceler, tari-hi ve eski yönlerin yüze çıkması, batı ülkelerinin etkisi ve iki ülke hükümetlerinin etkileşimi gibi faktörler milliyetçi hareketlere neden olmaktadır.

Anahtar kelimeler: Hükümet, Milliyetçi hareketler, Mimari, İran, Türkiye.

\section{Giriş}

Bir ülkenin mimari ve kentsel çevresini şekillendirme konusunda bir eğilim oluşturma ya da diğer ülkelerdeki mimari yaklaşımları takip etme, genel benzerliklerine rağmen kendine özgü farklılıklara ve özelliklere sahiptir. Bu farklılıklar ve benzerlikler ülkelerin siyasi, sosyal, tarihi ve kültürel alt yapılarından etkilenir. İlhan Tekeli'ye ${ }^{1}$ göre etraftaki diğer ülkeler üzerinde analizler yapmadan bu tür eğilimlerin özelliklerini anlamak ve mimarlık tanınması için teorik çerçevenin elde edilmesi mümkün değildir. ${ }^{2}$

\footnotetext{
* Doktora öğrencisi, Selçuk Üniversitesi, Mimarlık Fakültesi, Mimarlık Bölümü.

1 İlhan Tekeli, The social context of the development of architecture in turkey, In Modern Turkish Architecture, Pennsylvania: University of Pennsylvania Press, 2005, s.35.

2 Naser Hasanpour ve Hosein Soltanzadeh, "Background Factors in Contemporary Architecture Developments of Iran During the Second Pahlavi and Comparative Comparison with Turkey“, Bagh-e Nazar: The scientific jour-
} 
Ortadoğu bölgesinde ve I. Dünya savaşı sonrasında İran'da Rıza Şah, Türkiye’de Atatürk, Afganistan'daki Şah Amanullah Han ve diğerleri gibi güçlü ve karizmatik siyasi liderler, moderniteyi ve ulusçuluğu kendi yasalarıyla etkileşime sokacak bir projeye tanımlamışlardır ve hepsi kendi ülkelerini sadece bir dilek olarak değil, aynı zamanda ulusun canlandırılmasının bir yolu olarak modernleştirmek istiyorlardı. İran milletinin antik çağındaki görkemli geçmişini tekrardan canlandırmak Rıza Şah’ın ütopyasıdır. Pehlevi döneminden önce 147 yıl boyunca egemenliği süren Kaçar sülalesi, İran’ın zengin tarihi ve kültürel değerlerinden uzaklaşması ve siyasi açıdan Rusya'ya bağımlı kalması Pehlevi dönemi için çok üzücüdür. Dolayısıyla, İran sosyalizmi böyle utanç verici boyutları ortadan kaldırabilmesi için ciddi çabalar sarfetti. Bu durumda Rıza Şah, kendini ulusun birliğine götüren engelleri kaldırıp modernliğin onlarla olan vaatlerini üstlenebilen önde gelen bir teorisyen ve kral olarak görüyordu. Atatürk İran Kralı gibi büyük bir sorunla karşılaştı. Ulusun Osmanlı İmparatorluğunun kalıntılarından yeniden inşa edilmesi, geleceğin idealist bir resmini gerekli gördü. Atatürk, kendini ulusun bir temsilcisi olarak tanıttı ve gelecek olasılıkları yeniden gündeme getirdi. ${ }^{3}$

Çeşitli etnik ve dini cemaatlerden oluşan Osmanlı İmparatorluğunun Cumhuriyetin ulusal bir hükümetine dönüşümü, radikal bir değişimdir. Bu siyasal ve toplumsal değişimlerde, kültürel ve toplumsal hareketlerin ortaya çıkışı, dolayısıyla mimari eğilimlerin ortaya çıkması kaçınılmazdır. “Türkiye’nin Yirminci Yüzyıl mimarisinin Kısa Tarihi” kitabında Afife Batur, Türk mimarisinin bir eleştirmeni Türkiye’nin çağdaş dönemdeki mimari eğilimlerini ilk yıllar, geçiş dönemi (1923-1928), modernleşme dönemi (1929-1938), savaş yılları (1938-1950), savaş sonrası dönemi (19501960), yeni yöntemleri arama (1960-1980) ve dağılım ve yeni yöntemler (1980-2000) olarak altı genel döneme ayırmaktadır. ${ }^{4}$

Mimarlık entelektüel akımlarını tanımlarken, Afife Batur, Türkiye'de ulusal mimari hareketlerin ortaya çıkmasına yol açan faktörlerin ve çevresel koşulların esas olarak ilk dönem ve üçüncü dönemde meydana geldiğine inanmaktadır. ${ }^{5}$ İran'da Türk milliyetçiliğinin ilk dönemiyle birlikte, bölgedeki Pehlevi rejiminin oluşumuna, Türkiye ve Afganistan’ın milliyetçi hükümetlerinin kurulmasıyla birlikte genel bir politika eşlik etti ve dünyadaki modernizmin etkilediği yaşam biçimindeki değişimin mimaride yeni düşüncelerin kabul edilmesine yol açtı.

nal of Nazar Research Center, for Art, Architecture \& Urbanism, 13/44 (2017), s.40.

3 Sibel Bozdoğan ve Reşat Kasaba, Rethinking Modernity and Identity in Turkey, University of Washington Press, 1997, s.44.

4 Jamaleddin Soheili ve Darab Diba, "How Government Systems Have Influenced the Emergence of Nationalist Architectural Movements in Iran and Turkey", Bagh-e Nazar: The scientific journal of Nazar Research Center, for Art, Architecture \& Urbanism, 7/14 (2010), s.28..

5 Afife Batur, A Concise History: Architecture in Turkey throughout the 20th Century, The Chamber of Architects of Turkey, 2005, s.52. 


\section{Araştırma Yöntemi}

$\mathrm{Bu}$ çalışma tarihi bir incelemeye dayanarak niteliksel bir araştırma niteliği taşımaktadır. Araştırma tarihsel - yorumlayıcı yöntemini ele alıp yaklaşım olarak, İran ve Türkiye'nin belli dönemlerde yapılan mimari binalarının incelenmesinde çevresel, biçimsel ve anlamsal faktörlerin etkisine dayanmaktadır.

\section{Çağdaş Türkiye'de Ulusal Kimlik}

Türk milliyetçiliği başlangıçta edebi bir eğilim olarak kendini gösterdi. Yaklaşık 1860 yılına gelindiğinde, Ziya Paşa, Namık Kemal ve Ali Saavi gibi edebi şahsiyetler egemen dilini basitleştirme ihtiyacı konusunda Farsça ve Arapça terimler yerine Türk dilinin kullanılmasını talep ettiler. Cumhuriyet dönemi boyunca kimlik meselesi, Doğu-Batı, Dini-Laik, Milli-Evrensel gibi ikilemlerle karşı karşıya kaldı. Gelenek ile modernleşme arasında belirsiz bir bölgeye düşen konu, siyasi ve kültürel içtimaları etkiledi.

Coğrafi olarak Doğu ile Batı arasında ve tarihi olarak Asya (Anadolu), Osmanlı mirası ve en son Cumhuriyet mirası arasındaki karmaşıklıkta bulunan Türkiye, özünde daima birçok ikilemin kaynağı olmuştur. Örneğin, mimari bölümünde 1927'den kalan Türkiye Konut Birliği ve Milli Savunma Bakanlığı binaları, Cumhuriyetin kurulduğu ilk yıllardaki kültürel ikilemi sergilemektedir. Birisi, Neo-Osmanlı ilkelerine dayanarak bu yüzyılın ulusal akımını göstermektedir ve diğeri Avusturyalı mimarların getirdiği tamamen ülkeye yeni gelen batı tarzı mimarisi uygulanmaktaydı. ${ }^{6}$ Türk milliyetçiliği düşünce kuruluşu, yirminci yüzyılın ilk yirmi yıllarında tutarlı bir güç olarak geliştirildi. Dış baskılar, iç birleşim eksikliği ve Osmanlı İmparatorluğunda yok olan ulusal refah, yeni bir ittifak ideolojisini gerektiren bir ortam yarattı. Öte yandan, milliyetçi hareketlerdeki laiklik, Osmanlı İslam toplumu fikri ile çelişmekteydi. Dolayısıyla, toplumun maddi ve bilimsel yönleri bir uygarlık olarak ve değer sistemleri bir kültür olarak tanımlandı. Sonuç olarak kültür, Türk kimliği ve tutarlılığı arasında bir ayrım oluştu ve toplumsal ilerlemeye yönelik uluslararası bir yönelim düzenlendi. ${ }^{7}$

\section{Çağdaş Türk Milliyetçiliğinin Siyasal-Sosyal Değişmeler Üzerine Bir İnceleme}

Batı, Fransız Devriminden (1789) hızla çıktığında, Osmanlı İmparatorluğu bir durgunluk dönemine girdi. Ekonomik başarılar ve Avrupa uluslarının askeri ve bilimsel ilerlemesi Osmanlı liderlerini şaşkına çevirdi. İngiliz, Fransız, Avusturya ve Rus imparatorluklarıyla ticaret ilişkileri kuruldu ve Osmanlı İmparatorluğu ile Batı kapitalizminin Türkiye'de ilk resmi belgesi olan ticaret anlaşması 1838 tarihinde İngiliz devleti ile imzalandı. Bu dönemde Fransa’dan ve Britanya’dan seçilen Türkler yabancı müttefikleriyle buluşup bulgularını bildirdiler. Bu etkileşimin gelişme süreci, 1839'da “Tanzimat” başlıklı olarak tanımlandı.

“Tanzimat” ifadesi, kamu sektörünün tüm yönlerini rafine etmek, yeniden örgüt-

6 Aydin Balamir, "Modern Türkiye’de Mimari ve Yapılşma Kültürünün Kimliğì", Abadi, Mimari ve Kentleşme Dergisi, 38/3 (2003), s. 20.

7 Renata Holod, Modern Turkish Architecture, University of Pennsylvania, 2005, s. 9. 
lemek, birleştirmek ve geliştirmek için yapıldı. Bu arada, bunun hukuki bir reform olduğu gerçeğine rağmen, gelişmiş dünya ile uyumlu bir şehir hayatı vizyonu getirdi. " "Tanzimat" önce yasalar çerçevesinde eşitlik ilkesini vurguladı ve yaşamın tüm emperyal işlevleri için yaşam ve mülkiyetin güvenliğini garanti etti. Adli, eğitimsel ve mali alanlarda önemli düzeltici planlar uygulandı ve devletin uygulama yapısı değişti. Seçkinler tarafından yapılan "Tanzimat" reformları bir Batı yönelimi ile formüle edildi ve Avrupa kurum ve kuruluşlarının modellenmesi ile ilk kapsamlı ve tutarlı program olarak uyguland $1 .{ }^{9} \mathrm{Bu}$ nedenle, yapılandırma programının yapısal modeli yalnızca batı politik yöntemleri değil, aynı zamanda batı danışmanları tarafından planlama ve uygulama alanlarına da dayanıyor gibi göründü. İngiltere, Fransa ve Rusya gibi Osmanlı hükümetinin iç faktörlerini etkileyen ülkeler, planın uygulanması konusundaki görüşlerine ilham vermek için planlı bir çaba gösterdiler.

“Tanzimat" programı Avrupa sömürgelerinden alındı ve Avrupa’ya olan Osmanlı ekonomik bağımlılı̆̆ı büyüdü. Ekonomik bağımlılığı enflasyonla savaş takip etti, bu durum savunma harcamalarını artırdı ve sonuçta hükümetin yurtdışından sağladığı kredilere yönelik şartlar ağırlaştı. Sonuç olarak 1881 yılında Osmanlı İmparatorluğunun ekonomik koşullarını kontrol altına almak için Britanya temsilcileri tarafından yönetilen "Osmanlı devlet borcu” başkanlığ kuruldu.

Öte yandan, reform programının yöneticileri olarak, batı tarzında büyük maaşlar ve lüks yaşamlar yaşayan insanlar sürekli bir varlık gösterdi. Buna karşılık, "Genç Osmanlı Cemiyeti”, siyasi katılımı ve popüler bir hükümetin varlığını savunan siyasi fikirli kişiler tarafından 1865 yılında kuruldu. 1876'da Tanzimatın ilk anayasası ve bir parlamenter rejim kuruldu. Fakat II. Sultan Abdülhamid döneminde, başlang1cından birkaç ay sonra 1877 Rus Savaşı bahanesiyle Rusya ve Osmanlı İmparatorlugunun parlamentosu faaliyetlerini durdurdu ve tekelini tekrar güvence altına almak için istibdat politikasını uygulamaya başladı..$^{10}$

Birinci Dünya Savaşı sezgisel olarak Osmanlı İmparatorluğunun son yıllarına doğru gitmesi anlamındaydı. Mustafa Kemal, 1920'de Ankara'da ilk Ulusal Meclisi kurdu ve Yunanlıların Anadolu işgaline karşı Kurtuluş Savaşını (1920-22) başlatmak için Anadoluda bir gönüllü ordu topladı. Dolayısıyla, işgal kuvvetleri ülkeden kovuldu. Mustafa Kemal Türk hükümetinin modern bir devlet yaratma bütünlüğünü sağlamayı başard. ${ }^{11}$

\section{Çağdaş İran'da Ulusal Kimlik}

İran'da kimlik meselesini çözmek için İslam, İran ve Batı liberalizmi arasında bir tür uyum sağlanmalıdır. İran, bölgesel ve tarihsel bir kimlik kaynağıdır. İslam, manevi bir kimlik, inanç ve geniş bir sosyal-siyasal ideoloji kaynağıdır. Batı liberalizmi,

8 Hatice Aytaç, “The International Diffusion of Planning Ideas: The Case of Istanbul, Turkey”, Journal of Planning History, 6/2 (2007), s.116.

9 Bozdoğan ve Kasaba, Rethinking Modernity and Identity in Turkey, s.46.

10 Aytaç, The International Diffusion of Planning Ideas, s.116.

11 Bozdoğan ve Kasaba, Rethinking Modernity and Identity in Turkey, s.46. 
ekonomik, siyasi ve hatta kültürel kullanımları olan felsefi bir kaynaktır. ${ }^{12}$ Tabii ki, etnik, dini, edebi gibi faktörler yukarıdaki üç unsurun bir alt kümesidir. Rıza Şah’nn politikalarında görülecek olan şey, bu İslami niteliğin reddi, İslami unsurun kimliğinin ulusal kimlik üzerindeki etkilerini ortadan kaldırma girişimi ve İran unsurunun vurgulanmasıdır. ${ }^{13} \mathrm{Bu}$ nedenle, milliyetçi eğilimler arasında ilk Pehlevi döneminde ulusal kimlik statüsünün incelenmesi, tartışmanın yapısını şekillendirebilir gibi görünmektedir.

\section{Çağdaş İran Milliyetçiliğinin Siyasal-Sosyal Değişmeler Ůzerine Bir İnceleme}

Ulusal liberal kimlik olarak İran’lı liberal milliyetçilerinin en önemli özelliklerinden biri akıl, bilim ve ilerlemeye dikkat etmekti. Onların bakış açısından ilerleme yasanın varlığına bağlıydı ve kanun insanlığın bilgeliğinden alınmaktaydı. Liberal milliyetçiliğin savunucularına göre, Avrupa ülkelerinin ilerleme nedeni akılcı olan yasalar biçimiydi ve eğer bu kanunlar İran'da ortaya çıkarsa İran'da da Avrupa ülkelerinde olduğu gibi ilerleme kaydedileceği öngörülüyordu. Liberal milliyetçilik, İran’da dine sadakat yerine ulusa sadakat kurmaya çalıştı. Liberal milliyetçiler tarafından düşünülen ilkelerden biri de halkın özgürlügü ilkesiydi. Yani özgürlük, batı tarzındaki özgürlüğü ifade etmektedir; buna göre, eski gelenek ve göreneklerden ve dinlerden kurtulmak iyi bir şey olarak görülmektedir. ${ }^{14}$

Ulusal dini kimlik açısından ilk bakışta milliyetçilik din ile birleşemiyor gibi görünmektedir, çünkü milliyetçilik belirli hedefler izlemektedir. Ancak din insanoğlunu yönlendirme konusunda daha genel amaçlara sahiptir. Milliyetçilik ulusal egemenlik kurmayı amaçlarken, bu egemenliği sınırlayan din gibi faktörlerle kavga eder. İran'da milliyetçilik ile din arasındaki bağın nedeni, Şii din adamlarının hükümetten bağımsızlığıydı. İran tarihindeki dini milliyetçiliğin yönelimi baskınlığın hâkimiyetindedir. Dini milliyetçiliğin izlediği diğer önemli hedefler arasında, dış etkilerin sona ermesi ve İran’a karşı egemenliklerinin bastırılmasıydı. ${ }^{15}$

Ulusal eski kimlik açısından on dokuzuncu ve yirminci yüzyılları ulusçuluğun ve milliyetçiliğin etkili olduğu yüzyıllardır. Milliyetçiliğin, bu iki yüzyıl boyunca ve hatta yirminci yüzyılın başlangıcından bu yana, son yirmi yılda bile, etnik ve dilsel biçiminin ve dünyanın siyasi haritasını şekillendirilmesinde önemli bir rol oynamıştır. Bu nedenle, yirminci yüzyılın başında, küresel bir tanıma sahip olan modern milliyetçilik, İran’da küresel alana girdiğinde, İran milliyetçi tarihinin önemini iyi bilip bu tarihsel arka planda milliyetçilik duygusunu nasıl uyarabileceğinin farkında olduğu anlaşılmaktadır. Rıza Şah, milliyetçilik duygusunu uyarabilmek için İran antik mimarisini bir araç olarak kullanmış ve etkili olmuştur. ${ }^{16}$

12 Mahmoud Sari Al-Ghalam, İran Kimliğinde İslam ve Liberalizm Arasındaki Yüzleşme, Tehran: Jahad-e Daneshgahi, 2007, s.43.

13 Elaheh Koulaei, Iran'da Ulusal Kimliğin Süreci, Tehran: Jahad-e Daneshgahi, 2007, s.59.

14 Daryoush Ghamari, İran'da Milliyetçiliğin Dönüşümü, Tehran: Markaz-e Asnad-e Enghelab-e Eslami, 2001, s.72.

15 Ghamari, İran'da Milliyetçiliğin Dönüşümü, s.78.

16 Mostafa Kiani, Birinci Pehlevi Döneminin Mimarisi, Tehran: Moassese Motaleat-e Tarikh-e Moaser-e İran, 2004, s.67. 
Geçtiğimiz yüzyılda Avrupalı arkeologlar eski İran’n bilinmeyen tarihinin önemli bir bölümünü keşfettiler. Bu keşifler İranlı bazı düşünürlerin ve tarihçilerin İran milliyetçiliğine atıfta bulunarak onları güçlendirmesi için bir bahane oluşturdu. Eski milliyetçilik İslamın önündeki kültürel başarıları övdü ve İslamiyet döneminde bu kültürün zenginliği nedeniyle İran halkının ve onun kültürünün hayatta kalmasına dayanan bir eski Sasani İmparatorluğu kültüründen kalan izleri aramaya çalıştı. Bu milliyetçilik batıl inançla İranlılı̆̆a dayanıyordu ve İranlılık ile yabancı bir din olarak İslam ile savaşıyordu. Dolayısıyla İslamı görmezden gelerek yeni bir İran dinini yaratmak veya geçmişteki İran dinini canlandırmak istiyordu. ${ }^{17}$

\section{Türkiye ve İran Devletinin Ulusal Kimliğini Güçlendirmek İçin Gösterdikleri Çabalar}

Yirminci yüzyılın ilk yıllarında İran ve Türkiye’nin siyasi ve kültürel etkileşimlerinin milliyetçi hareketlerini şekillendirmede İran-Türkiye etkileşimlerinin rolü iki aşamalı olarak incelenebilir: Birincisi, ilişkileri derinleştirmek için İran devlet başkanları ile Türkiye arasında politik bir ilişki kurulması ve ikincisi, İki ülkenin entelektüelleri arasında kültürel ve sosyal ilişkilerin ortaya çıkışı, İran'da popüler politik olaylara ve kültürel olaylara neden oldu. Ortadoğuda Türkiye ve İran, I. Dünya Savaşından sonra ve Türkiye bağımsızlık savaşından sonra uluslararası siyasi sistem içerisinde en erken ortaya çıan iki hükümettir. Kendi kaderini yöneten devletlerin unvanları ortaya çıkmış ve politikacıların küresel siyaset sahnesindeki varlıklarını en üst düzeye çıkarmak için tutumlarını sürdürmüşlerdir.

Türkiye, Birinci Dünya Savaşının acımasız olaylarını tetikledi ve Sovyetler Birliği, Fransa, İngiltere, İtalya, Romanya, Yugoslavya ve Yunanistan ile bir dizi ikili anlaşma imzaladı. Riza Şah’n 1934'te Türkiye’ye yaptığı ziyaret, İran'daki modernlik ve ulusal kimliğin meydan okumalarını etkileyen önemli bir kültürel ve siyasi anlam taşıyordu. Bu resmi ziyaret, iki ülke arasında halk için planlanmış ve her iki liderin tam milliyetçi planlarının döneminde sergilenmiş ve Türkiye ile İran’ın yeni ulusal kurumlar kurması için bir firsat oluşturmuştur. Bu nedenle, İran hükümeti yeni kurulan Türk cumhuriyeti ile olan ilişkilerini genişletti ve son 150 yılda Türkiye'nin reformlarını ikinci kez taklit etti. Fakat bu taklidinin önemi on dokuzuncu yüzyılınki ile kıyaslanmazdı, Türkiye'de modernitenin ortaya çıkışı ile doluydu ve Türkiye'deki değişimlerin ana tezahürünü, din-hükümet arasındaki ayrım, alfabe değişikliği, takvim değişikliği, halkın siyasi katılımıydı. ${ }^{18}$

17 Soheili ve Diba, "How Government Systems", s.32.

18 Jamshid Behnam, Iran’llar ve Yenilenme Düşüncesi, Tehran: Nashr va Pazhouhesh-e farzan Rouz, 2007, s.18. 
Türkiye ve İran'ın Ulusal Mimarlık Hareketi Görünümüne İlişkin Hükümet Kimlik Beyanının Etkisi

\section{Başlangıcından İtibaren Türkiye’de Mimarlık Milliyetçiliği}

Yirminci yüzyılın başında, çağdaş Türk mimarisi, bölgedeki bazı ülkeler gibi, siyasi ve sosyal yapılarda dâhili hareketlerden ve diş güçlerden etkilenen temel değişimlerden dolayı çeşitli dönemlerde çeşitli mimari gelişmelere uğradı. Giriş bölümünde de belirtildiği gibi, Türk mimarinin eleştirmenlerinden bazıları, sonraki iki dönemi, Türk hükümetinin politikalarının milliyetçi hareketlerin ortaya çıkışını nasıl etkilediğini anlatan bir Osmanlı yeniden canlanma dönemi olarak görüyorlardı:

Kuruluş Dönemi (1923-30): Kurtuluş Savaşından (1920-1922) ve 1923’te Türkiye Cumhuriyeti’nin ilanından sonra yirminci yüzyılın ikinci on yılının başlaması, doğal olarak ülkenin 1. Dünya Savaşı sonrası durumunu kötüleştirdi. Bu ülkedeki reformlar, Osmanlı İmparatorluğu kalıntıları üzerinde ulusal bir hükümet kurmaya çalıştı. Mimarlık ve kentsel planlama alanında fonksiyonel öncelikler şu şekilde sunulmuştur:

1. Yarı bitmiş binaların kamulaştırılması ve ulaşım ağının geliştirilmesi gibi mühendislik yatırımlarıyla birlikte hizmet binalarının inşası.

2. Savaş sırasında yıkılan Anadolu kentlerinin restorasyonu ve küçük ölçekli hizmet binaları inşaatı.

3. Ankara’yı yeni başkent yapmak. ${ }^{19}$

$\mathrm{Bu}$ dönemde inşa edilen binalar ya Osmanlı mimarisinin özelliklerine uygundur ya da Avrupa mimarisi özelliklerine benzemektedir. Örneğin, İstanbul'da yapılan Harikzadegan Evleri veya Tayyare apartmanı I. ulusal/neoklasik dönemin eserlerinden olup, Mimar Kemaleddin Bey tarafından 1923 yılında planlanmıştır. Bu bina ilk betonarme ve toplu konut projesi olarak mimarlık tarihine geçmiştir. Diğer örnek olarak Vedat Tek’in tasarladığı ikinci TBMM Binası (Halk Fırkası Kulübü) 1924 yılında Ankara'da neoklasik üslûbun yansımasıdır. 


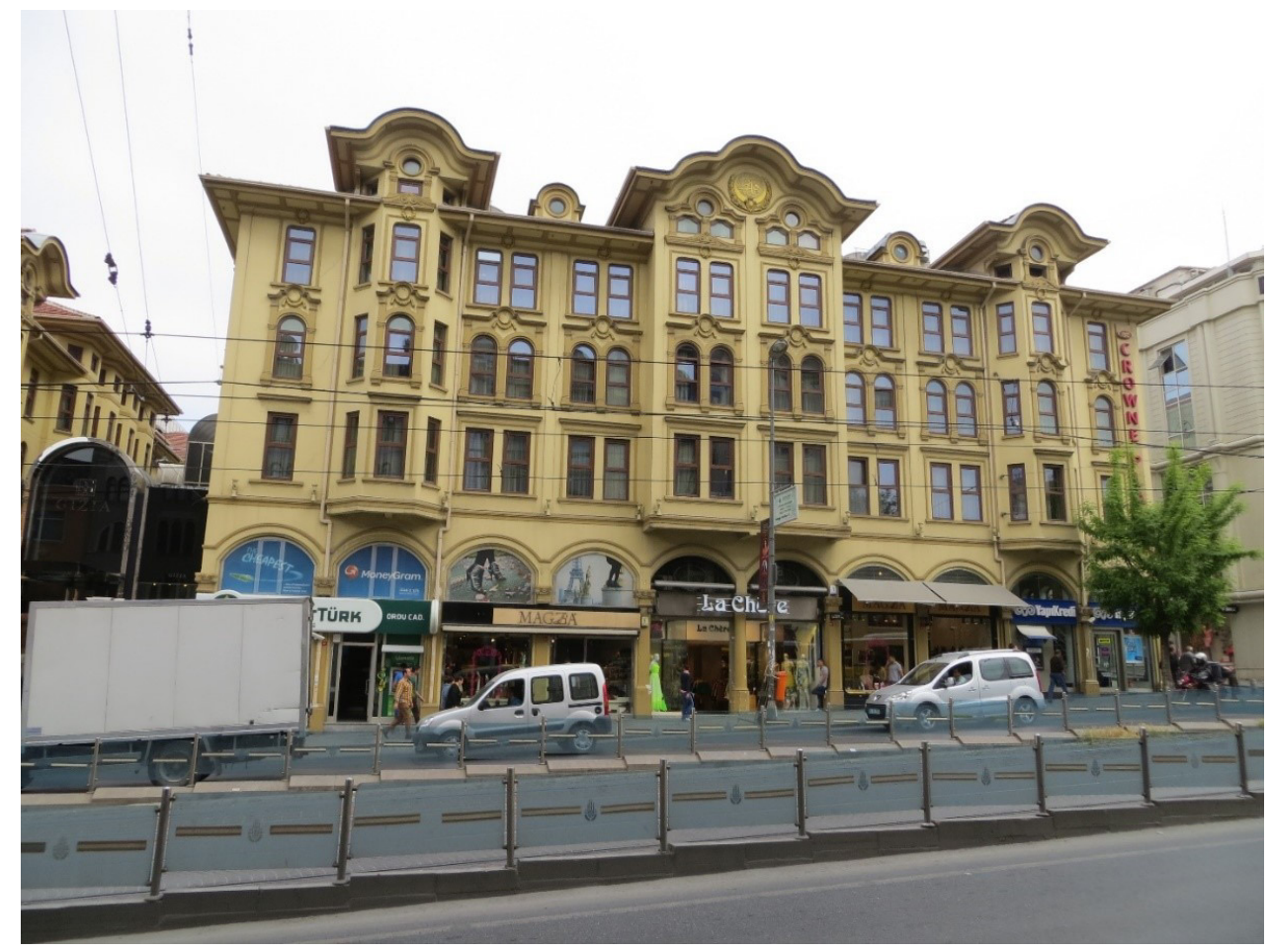

Resim 1. Tayyare apartmanı, İstanbul, (1923)

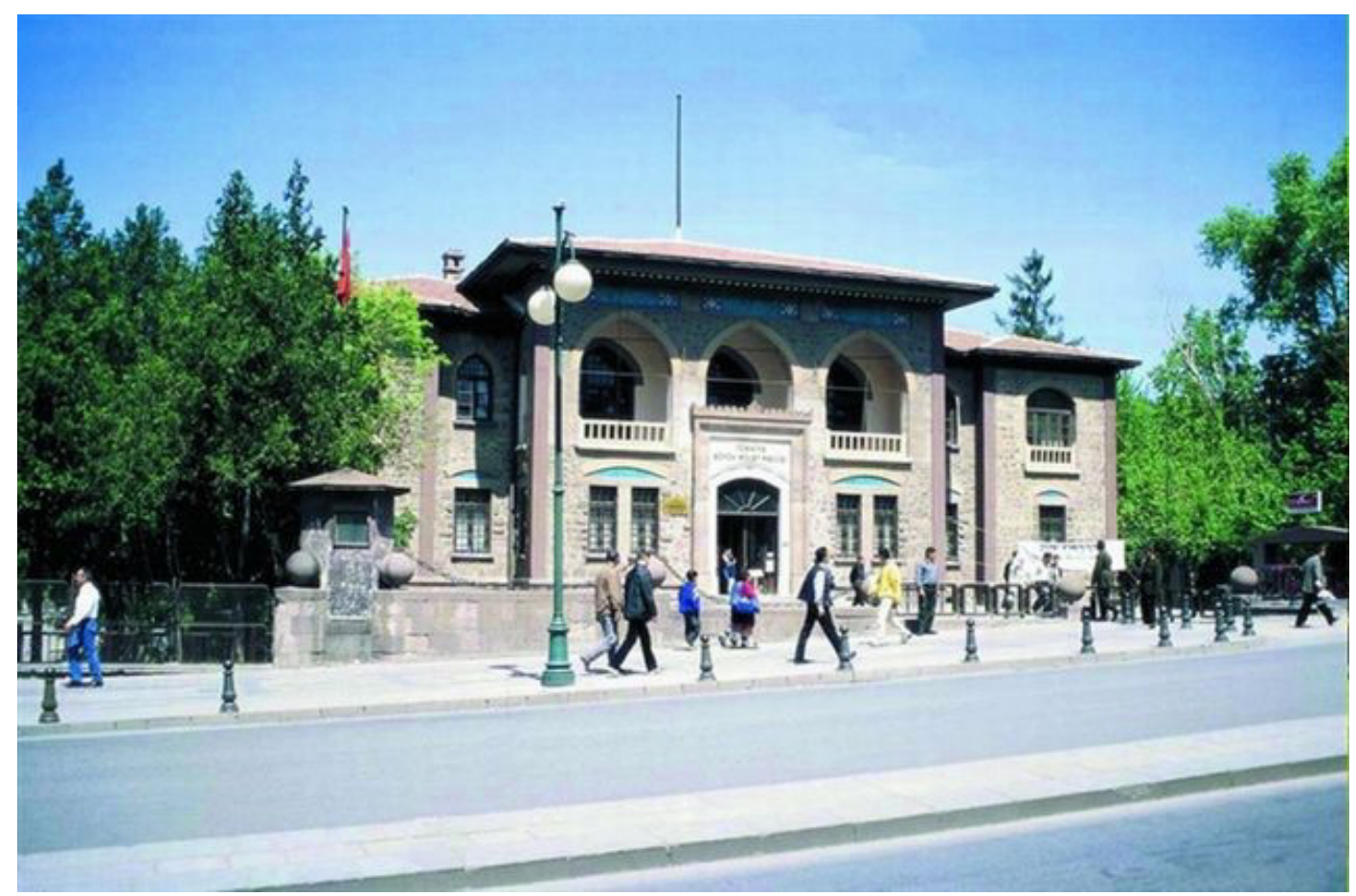

Resim 2. Halk Fırkası Kulübü, Ankara,(1924) 


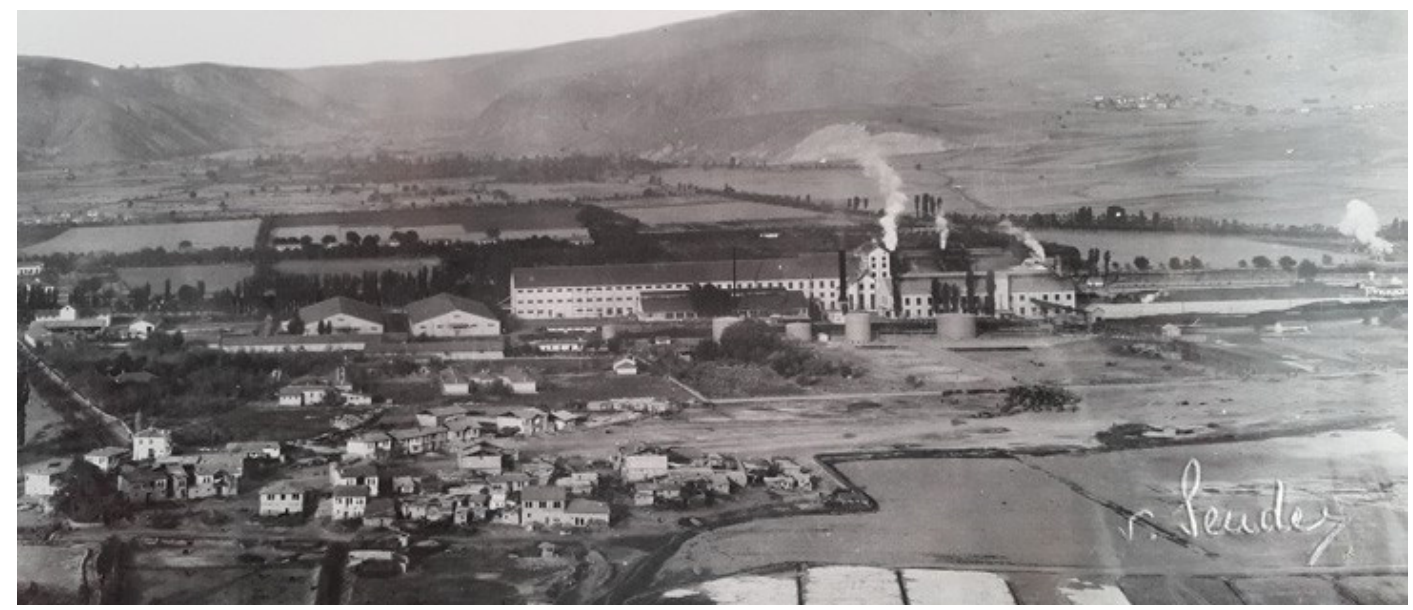

Resim 3. Alpullu Şeker Fabrikası, (1926)

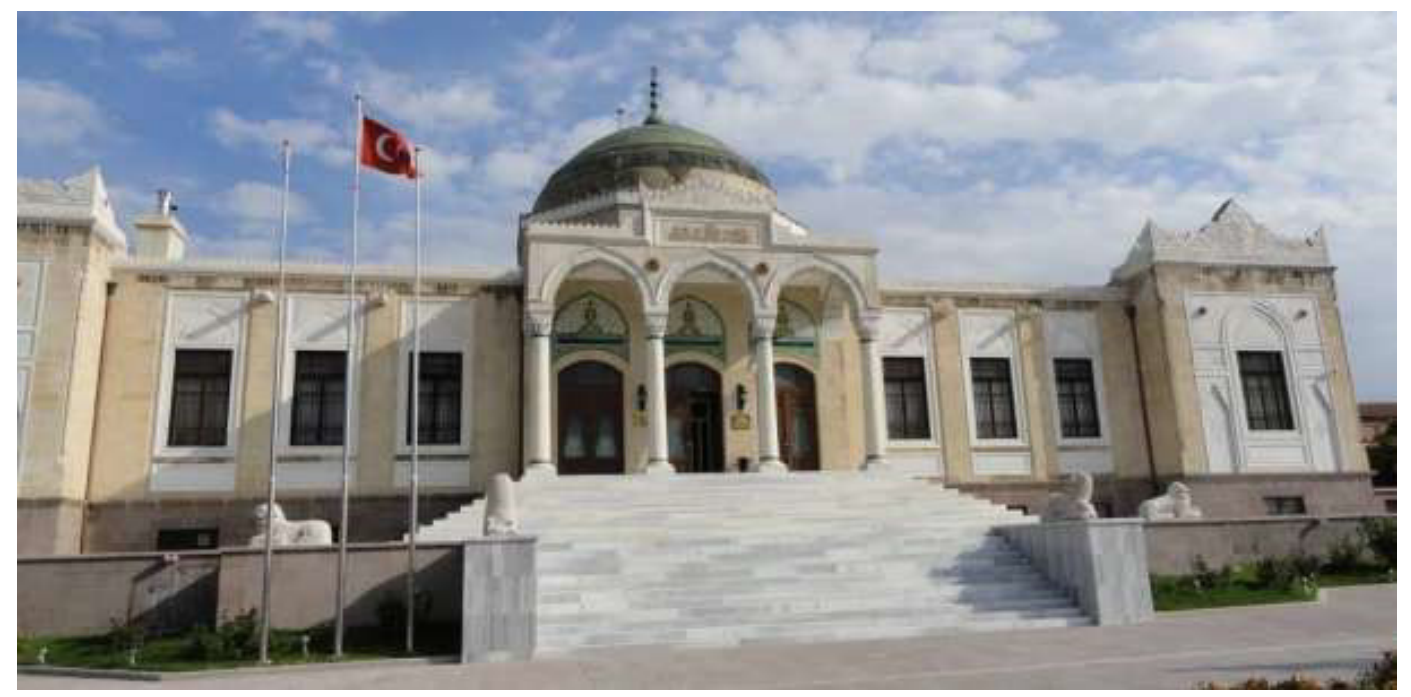

Resim 4. Antropoloji Müzesi, Ankara, (1928)

Cumhuriyetin ilk yıllarında yabancı mimar ve şehir plancıları ülkeye davet edildiler. Önemli kamu yapılarının ve şehir planlarının hazırlanmasında önemli roller üstlendiler. Bu isimlerden bazıları mimarlık ve planlama eğitimi veren kurumlarda, eğitimi yeniden düzenlediler. Örneğin Sanayi-i Nefisede Ernst Egli, «Modern mimarlığın» altyapısını hazırldı. İTÜ Mimarlık Fakültesinde Holzmeister Türkiye’nin ilk şehir plancılarını yetiştirdi. 1933 yılında belediyelerin kentleşme sorunları karşısında yetersiz kalan finans ihtiyacını karşılamak amacıyla, İLBANK (Belediyeler Bankası) kuruldu. Artan konut açığını karşılamak üzere toplu konut uygulamaları başladı. ${ }^{20}$

Mimar Giulio Mongeri’nin tasarladığı Ziraat Bankası 1926-1929 yıllarında, birinci dönemin Türkiye mimarlığına ve planlamasına katkı veren yabancı mimarların önemli eserlerinden biridir. Ayrıca, Ankara Palas (Vakıf Oteli) 1924- 1927 Vedat Tek ve Kemaleddin Bey’in tasarladığı bina neoklasik akımın önemli yerli temsilcileridir.

20 Ahmet Alkan, “Türkiye’nin Kentleşme Deneyiminden Öğrenmek”, International Conference on Civil Engineering, Architecture \& Urban Management in Iran, Ferdowsi University of Mashad, December 19, 2018. 


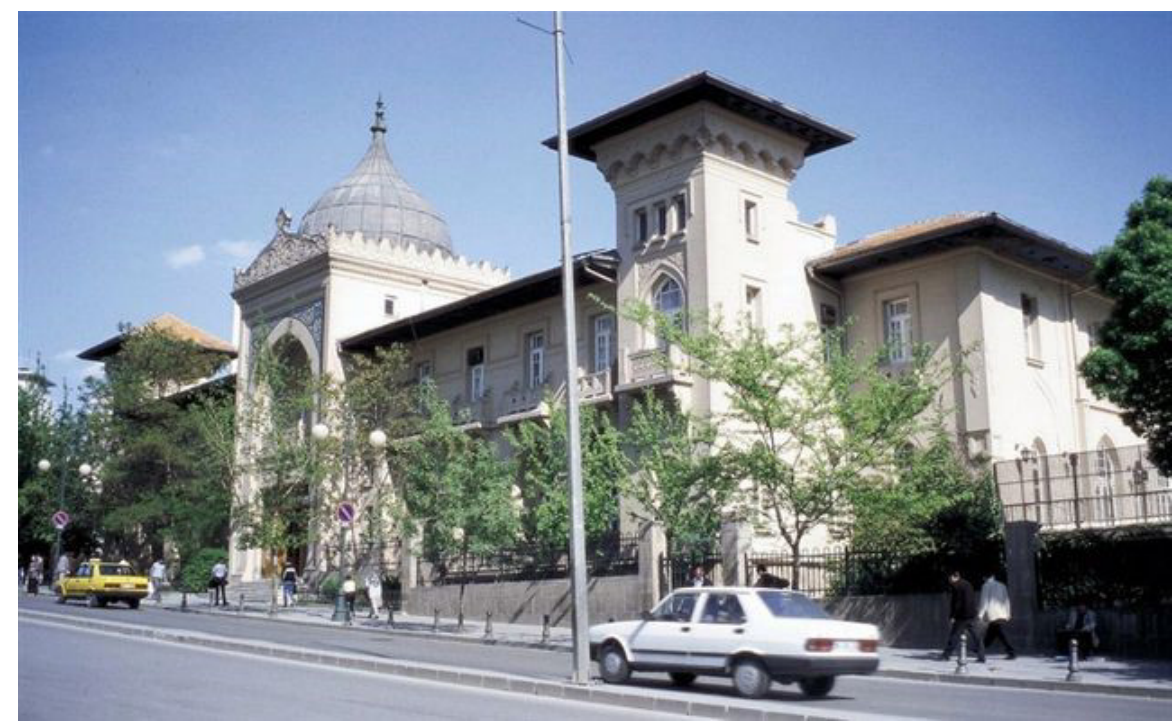

Resim 5. Vakıf Oteli, Ankara, (1927)

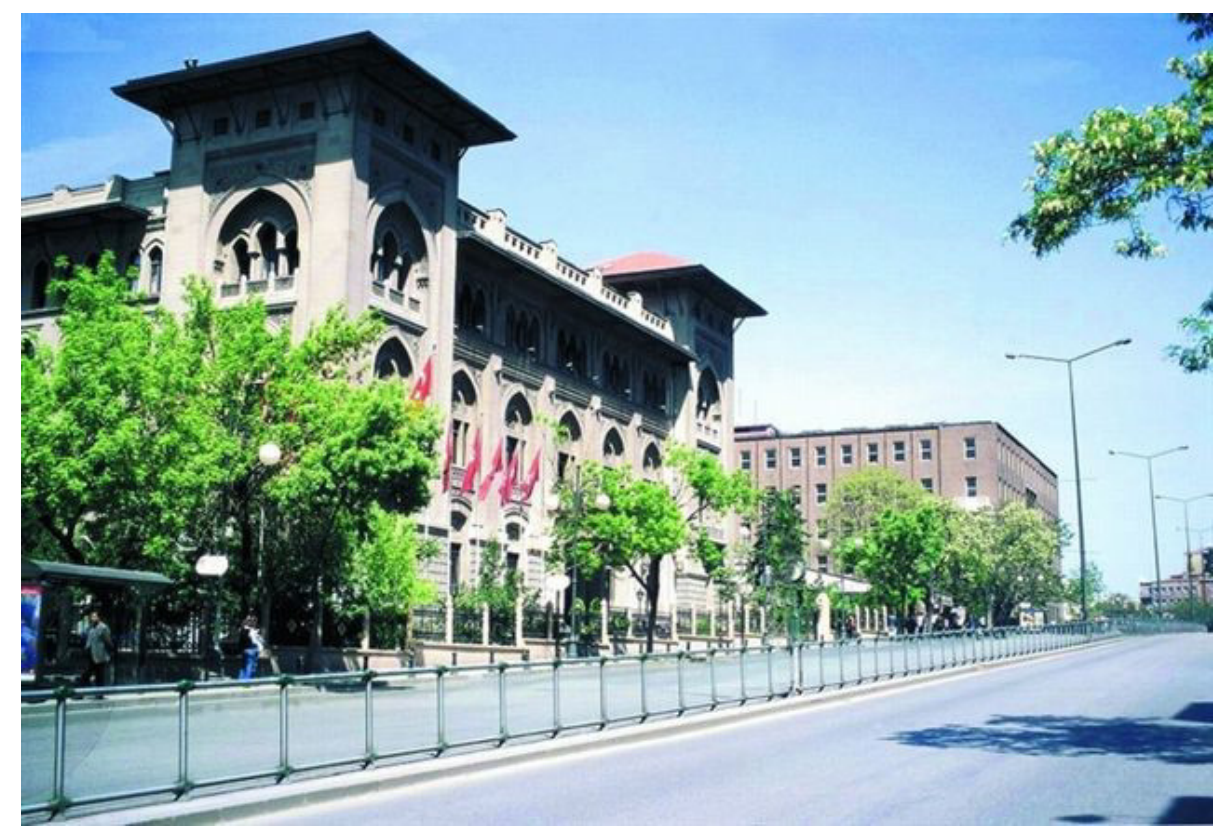

Resim 6. Ziraat Bankası, Ankara, (1929)

1928-30 Yıllarında Ankara'da yapılan İkinci Vakıf Apartmanları kentleşmenin hissedilmeye başlandığı dönemdir. Aynı zamanda çözüm arayışlarını da başlatmıştır. Bu yıllarda, sanayi ve altyapı yatırımlarında olduğu gibi, kentsel mekân üretiminde de kamu yatırımları öncülük etmiştir (Genel Kurmay Başkanlığı Binası). ${ }^{21}$

21 Alkan, “Türkiye’nin Kentleşme Deneyiminden Öğrenmek”. 


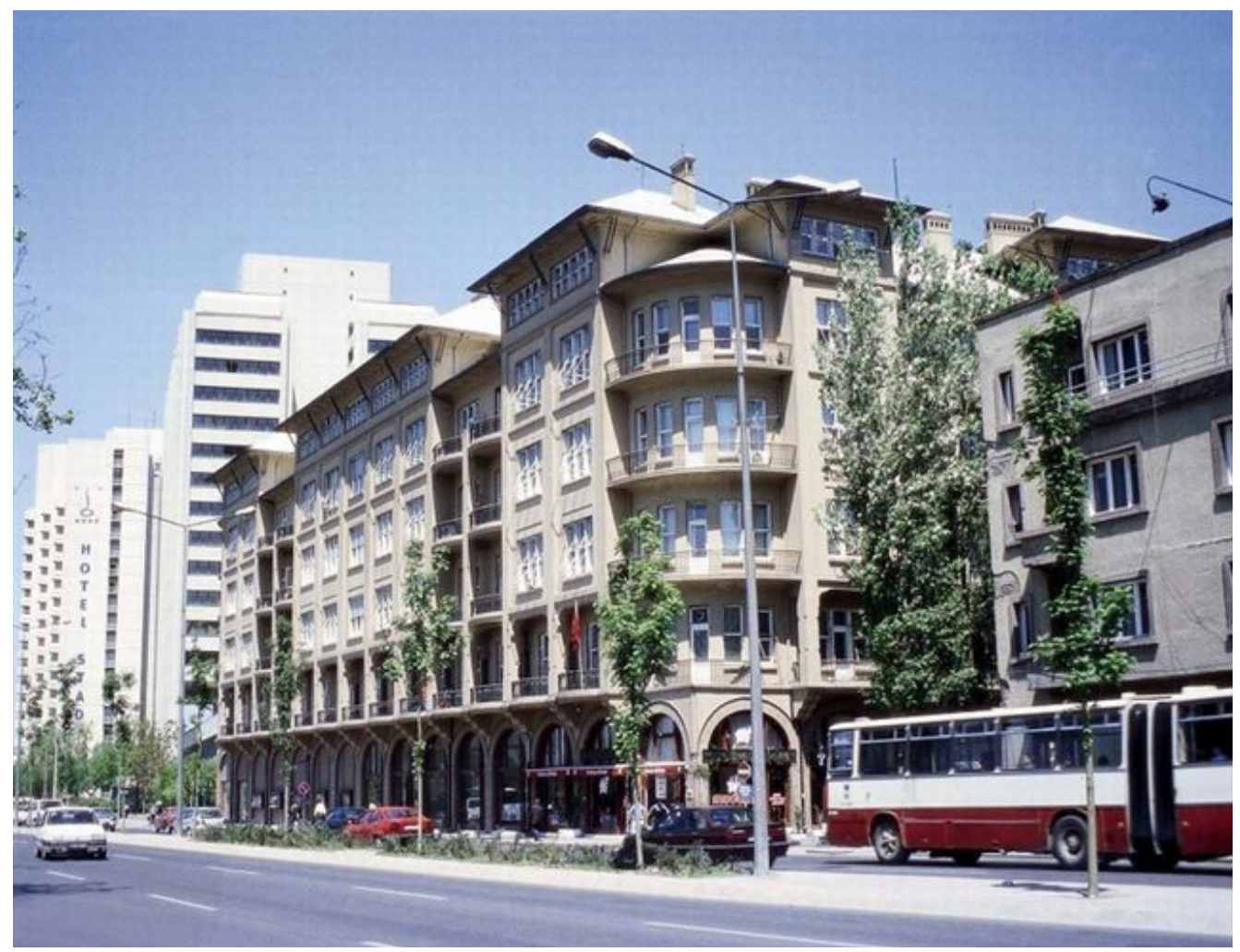

Resim 7. İkinci Vakıf Apartmanları, (1930)

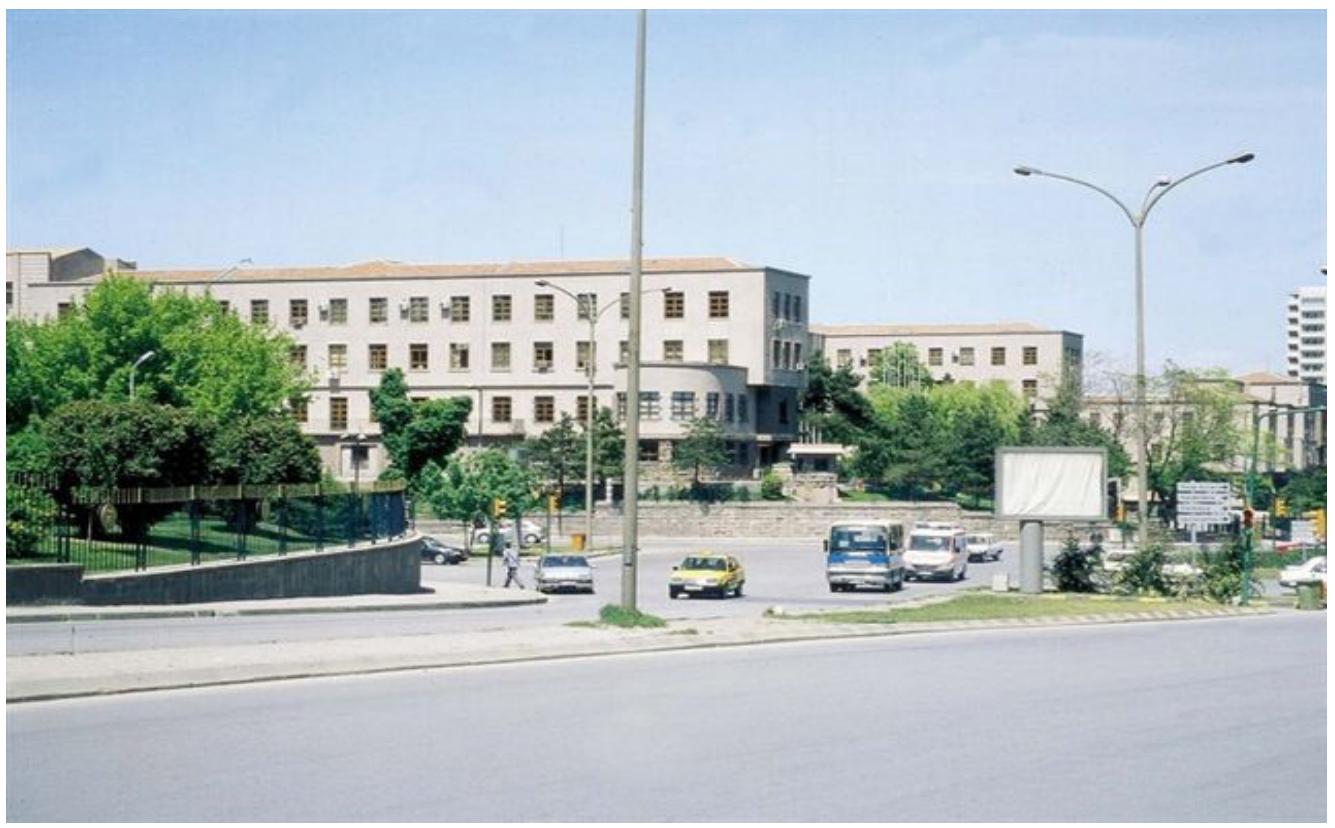

Resim 8. Genel Kurmay Başkanlığg, (1930)

Savaş Yilları (1938-50): Üstun İlhan Tekeli gibi güncel çağdaş Türk mimarlık eleştirmenleri 1938-1950 yıllarını Türkiye Modernist Mimarlık Kitapında milliyetçi mimarlık hareketlerinin ikinci dönemi olarak adlandırmışlardır. Bu dönemlarde Türkiye mimarisinde milliyetçiliğin yeniden ortaya çıkmasında birçok neden vardır; 
bunlar şöyle özetlenebilir:22

1. II. Dünya Savaşından kaynaklanan ekonomik kriz, çelik, cam ve çimento gibi inşaat malzemelerine erişim eksikliği.

2. II. Dünya Savaşının psikolojik etkisinden dolayı dış baskılara dayanma ve direnme duygusunun güçlenmesi.

3. Kentsel görüntülerde uyum ve bütünlügü sağlamak için Türk mimari tarzını belirleyebilecek yasaların oluşturulmasında ilgili bakanlıkların desteği.

4. Ankara, Sovyetler Birliği ve İtalya arasındaki ilişkilerin güçlendirilmesi.

Milli Mücadelenin İkinci Hareketi’nin milliyetçiliğin ilk hareketi ile olan temel farklılıkları ve benzerlikleri vardı; bunların en önemlisi Afife Batur'un görüşüne göre şu şekildedir: $:^{23}$

Yerel: Bu yaklaşımda mimarlar, yerli malzemeleri kullanarak ve iklim koşullarını dikkate alarak mimaride kültürel sürekliliği göz önünde bulundururlar. Bu yaklaşım, bölgesel unsurların ve akılcı (bireyselci) ilkelerin kombinasyonunda milliyetçilik arayan süreçtir. Aslında bu yaklaşım, Anadolu kent mimarisini Osmanlı coğrafyasıyla değiştirmeyi amaçlıyordu. Bu bağlamda, İstanbul Teknoloji Üniversitesi Mimarlık Okulu’nda görev yapan bir grup personel, Anadolu Konut Mimarisi konusuyla ilgili güçlü çalışmalar yaptı. Başkentte konut açığı hissedilmeye başladı. Devlet Mahallesi, Subay Evleri, Amele Evleri vb. meslek gruplarının veya devrin ünlülerinin isimleriyle anılan toplu konut uygulamaları başladı.

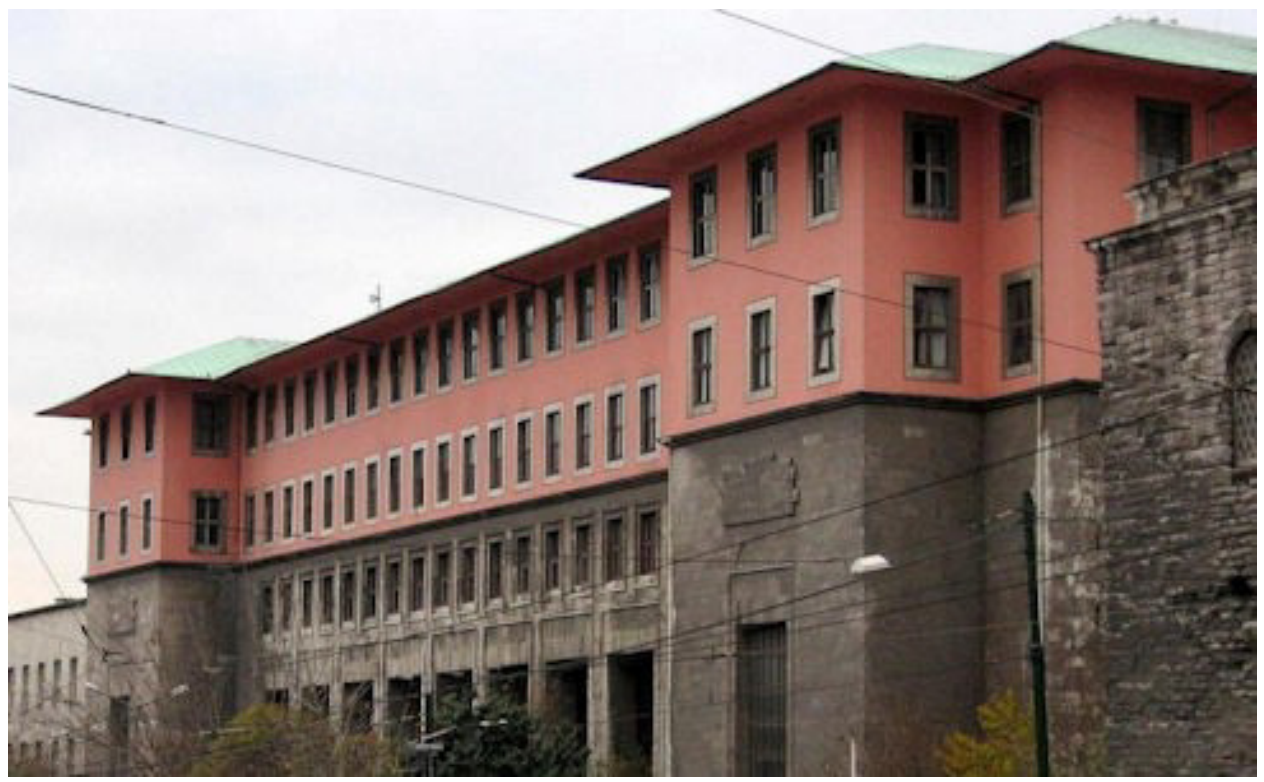

Resim 9. İstanbul Üniversitesi, Fen Fakültesi

22 Hasanpour ve Soltanzadeh, "Background Factors in Contemporary Architecture", s.45.

23 Soheili ve Diba, "How Government Systems”, s.35-37. 


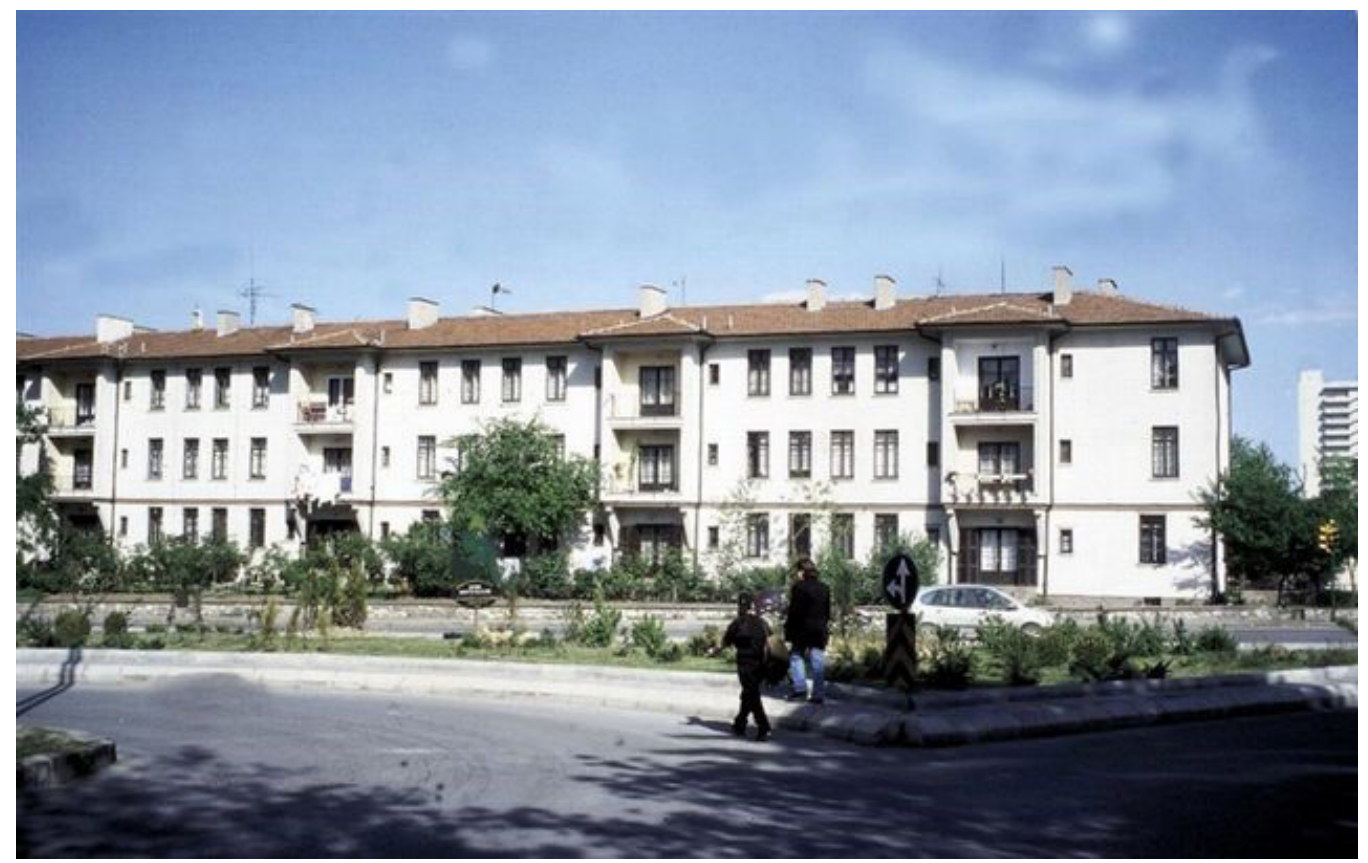

Resim 10. Saraçoğlu Mahallesi (1945-46)

\section{Nostaljik ve Geçmiş Düşünme Yaklaşımı}

$\mathrm{Bu}$ yaklaşımla geçmişin değerlerinin hala geçerli olduğunu göstermeye çalışıldı. Bu eğilimde, plan diyagramlarının tasarım ilkelerine ve kriterlerine ulaşma, geçmiş planların boyutları, oranları ve mimari biçimleri- temelde tarihsel planların seçimi ve doğrudan kullanımı - değil de ana hedefin analizi yoluyla sağlandı.

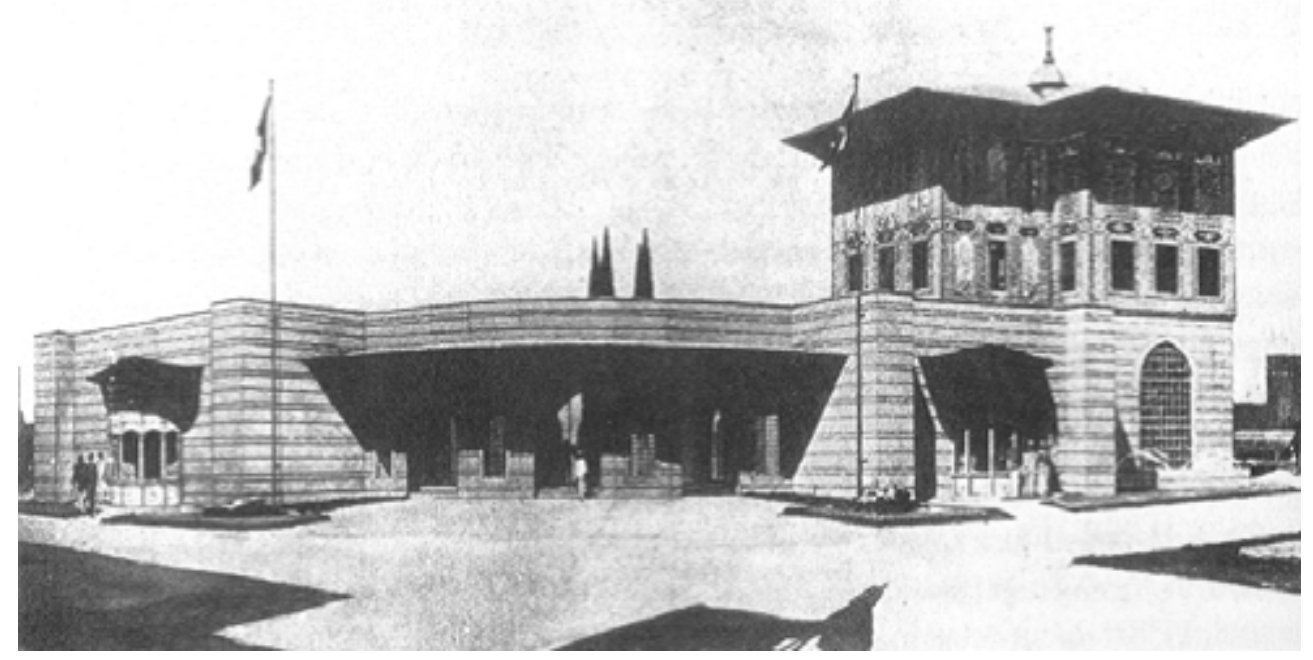

Resim 11. Doğu Kahve Evi, İstanbul, (1948)

\section{Anma ve Akademik}

Bu yaklaşımda modern batı mimarisi ilkesi kullanılmış ve milliyetçi düşüncesi mimari unsurlarda, pencereler, sütunlar gibi modern teknikler ve malzemeler kul- 
lanılarak ortaya çımıştır. Bu yaklaşım, anıtsallığı mimari bina yoluyla vurgular. Atatürk'ün kabri olan Anıtkabir bu yaklaşımın bir örneğidir. Bu fikir, Selçuklu ve Osmanlı mimarisinin mirası yerine Türk milliyetçi fikrini genişleten Cumhuriyetçi politikacıların düşüncelerini net olarak göstermektedir.

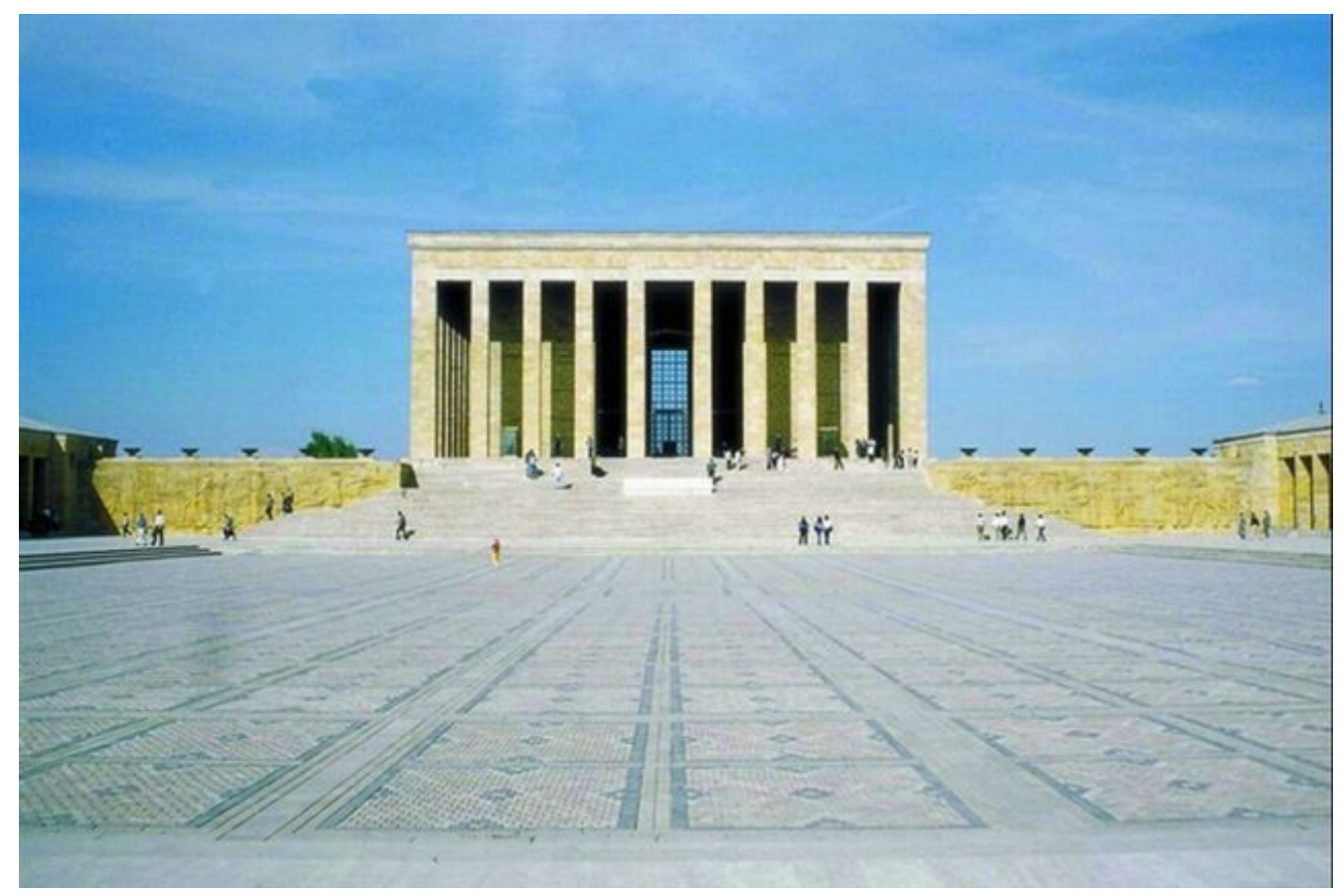

Resim 12. Anttkabir, Ankara, (1942-53)

1950 Sonrası Yilları: 1950 yılında, savaş sonrası krizin etkisinden dolayı, yeni bir parti olan Demokrat Parti iktidara gelmiştir. Bu yıllarda, Amerikan sempatisi artmış, Amerikan kültürü toplumsal, kültürel ve sosyal yaşamdaki etkisini mimaride göstermişti.

1950 sonrası; Türk siyasi hayatında ve kentleşme sürecinde önemli bir dönüm noktasıdır: çok partili hayata geçiş, ekonomide dışa açılmanın hızlanması, tarımda mekanizasyon, kırdan kente büyük göçlerin başlaması, gecekondulaşma ve kentsel alt ve üst yapıda sorunların artışı bu dönemin özelliklerindendir. Aslında, 1950 sonrasında modernizm diye yeni bir dönem başlar; Kalkınma sürecindeki Türkiye, özellikle büyük şehirlerinde kültürel tesislerin yapımına da başlar. Bu olgu toplumda «total kalite» yi tanımlayan önemli kriterlerden biridir. ${ }^{24}$ 


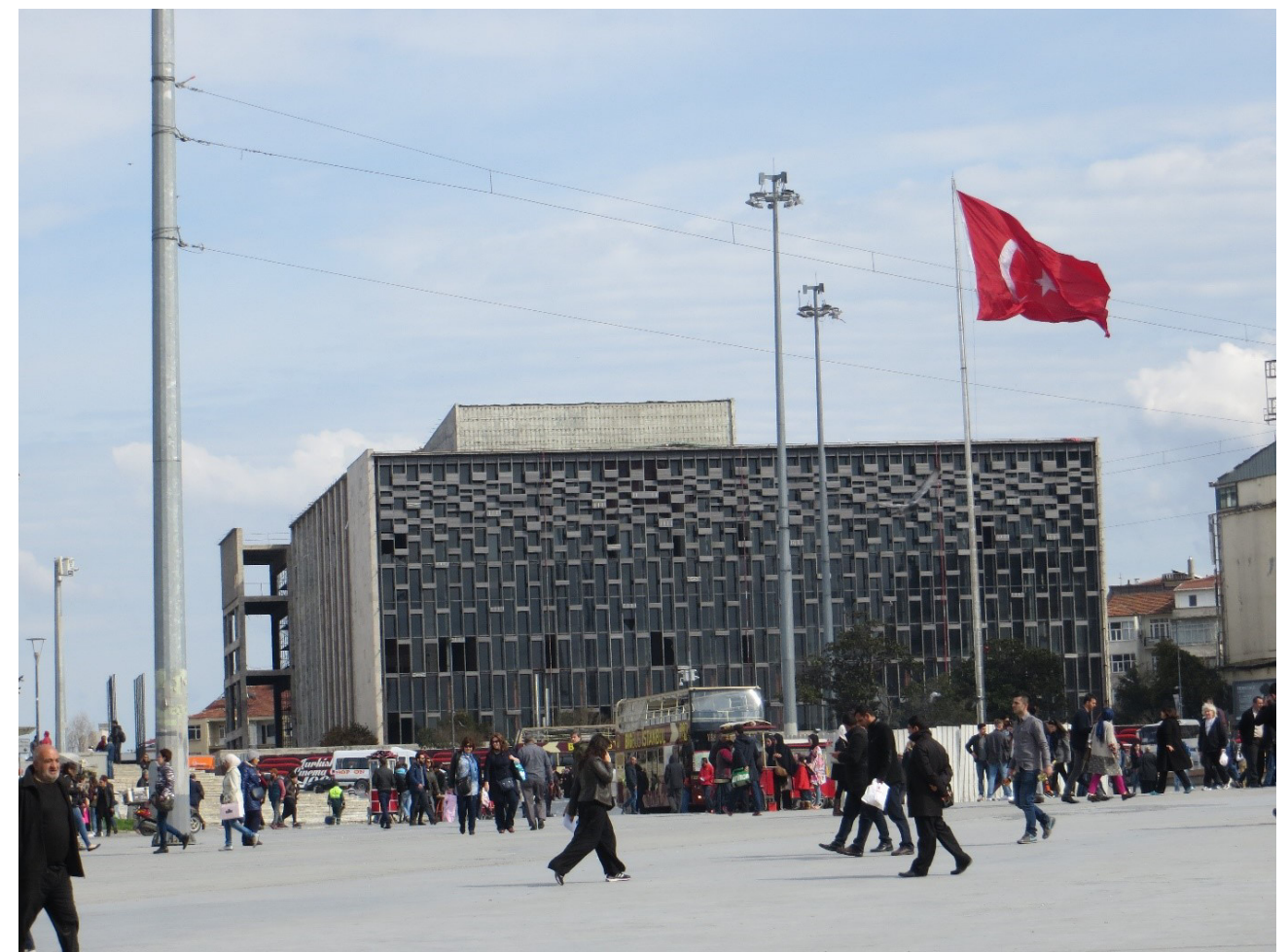

Resim 13. Atatürk Kültür Merkezi, İstanbul

\section{İlk Pehlevi Döneminde İran’da Mimarlık Milliyetçiliği}

Çoğu eleştirmene göre, İran’ın tarihi sürekliliği içindeki mimarisi, Kaçar döneminin sonuna doğru iç ve dış faktörlerden etkilenmiş ve orijinalliğini ve kimliğini koruyarak çeşitli iniş ve çıkışlar yaşımıştır. Pehlevi döneminin başlangıcında İran esas olarak dış etkenlerden etkilenen değişikliklere tanık oldu. Bu gelişmeler mimari alanda "dönüşüm ve gelişme" ve "dönüşüm ve geçiş" dönemi olarak adlandırılan çeşitli siyasi, kültürel ve sosyal alanlarda gerçekleşir. Mimarlık milliyetçiliği alanında pek çok bilim adamı, bu yaklaşımın mimarlarının İslam öncesi mimari unsurları kullanmaya çalıştığını düşünmektedir. Bu nedenle, ilk Pehlevi döneminin mimarisinde, arkeolojik mimariye yönelik hükümetin özel dikkatine rağmen, arkeolojik deneyim yaşarken bu devrin mimarları dikkatlerini İslam sonrası mimari faktörlere ve bazen de İslam öncesi ve ulusal bir dini kimliğin uygulanması yoluyla İran mimarisinde ulusal kimliği açıklamaya çalıştı. Dolayısıyla, ilk Pehlevi dönemi İran mimarisindeki milliyetçiliğin başlangıcı olarak, bu akımların toplumsal eğilimlerini etkilemek için üç baskın yön temel alarak ortaya çıktı:

Modern Batı Mimarisine Eğilimli Milliyetçi Mimari: İlk Pehlevi döneminde modern Batı mimarisi eğilimi gösteren milliyetçi mimarlık, çeşitli alanlarda Alman danışmanların varlığı ve antik dönem sempatik yaklaşımların aktarılması ve Avrupa faşist diktatörlüğünün İran’a egemen olması, mimarlık alanında bu temelli gelişmelerin bir bölümünü oluşturdu. Tahran şehri ve Tabriz, Urumia, Şiraz, Raşt, Gorgan ve diğer şehirler gibi hükümet binalarının yapım ortamında çoğunlukla Alman şirketleri ve mühendisleri faaliyet gösterdiler. Binaların cephesinde İslam öncesi mimari 
ile ilgili belirli dekorasyonların korunmasıyla modern Batı mimarisinin kalıplarına dayanan bir tür mimari milliyetçiliğin oluşmasına öncülük etti. ${ }^{25}$

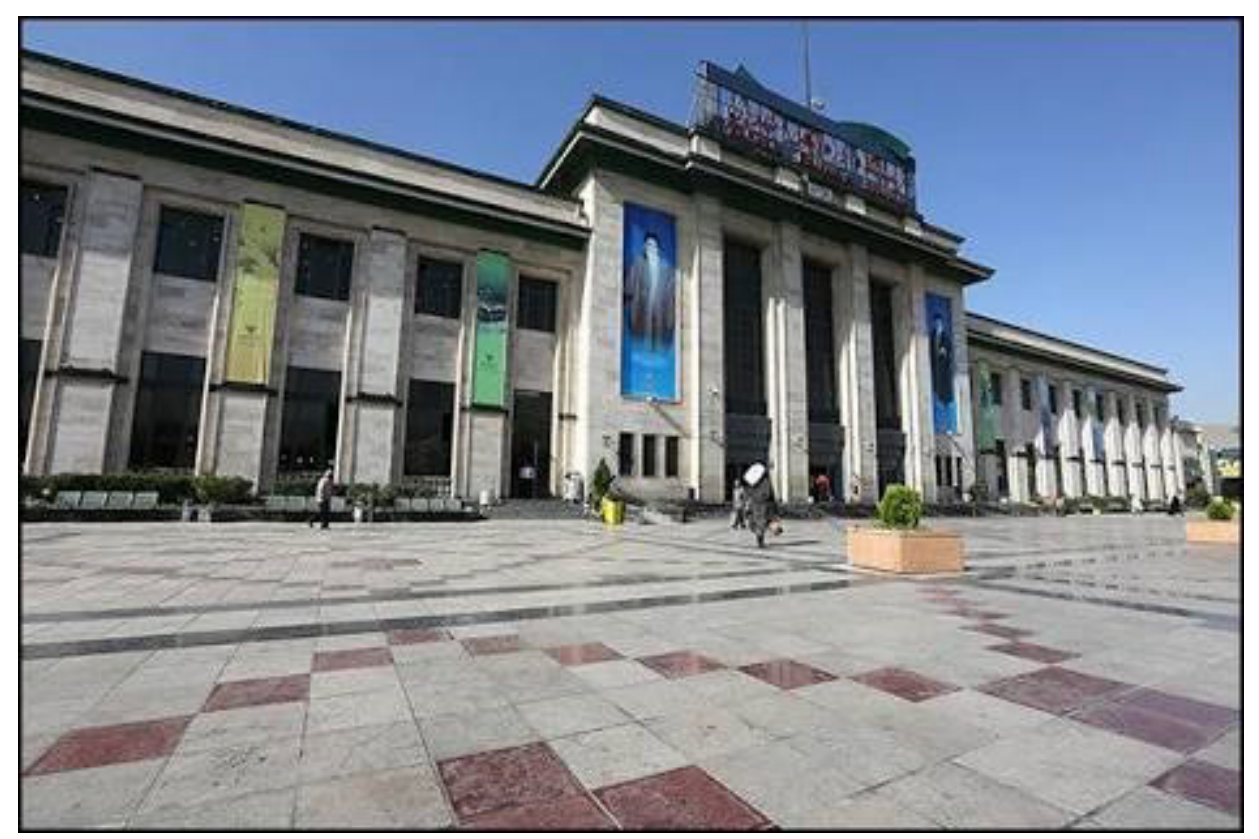

Resim 14. Tahran Tren Garı (1927)

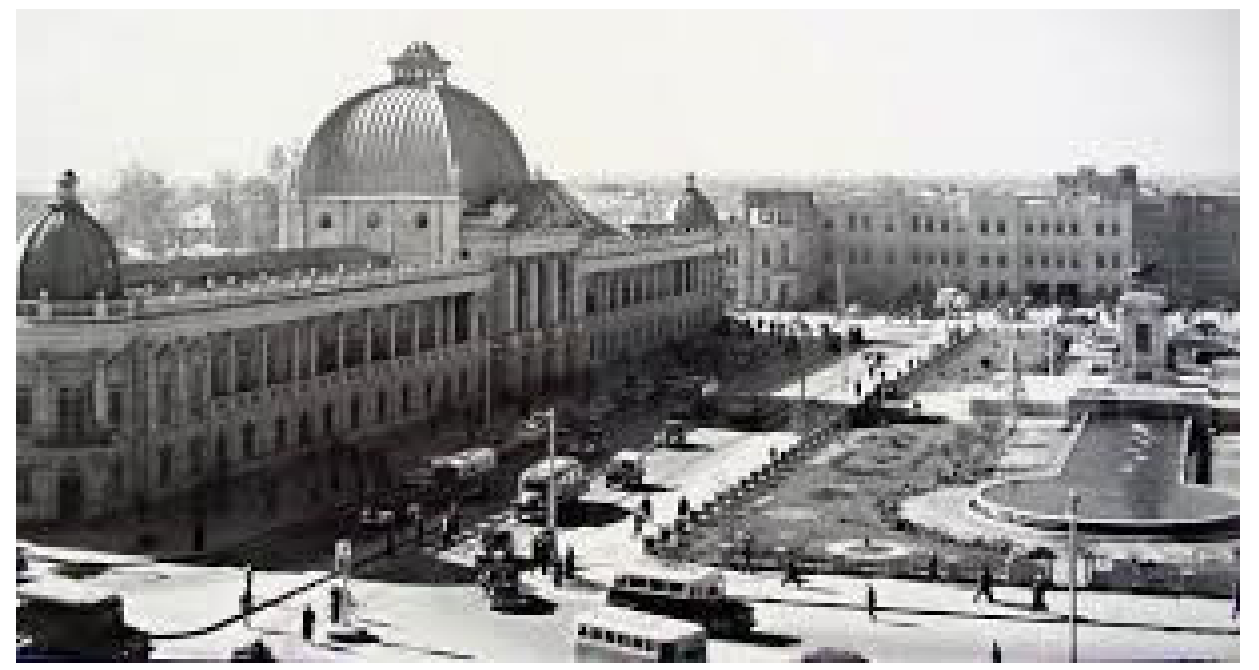

Resim 15. Telgraf Binast, Tahran (1928)

25 Soheili ve Diba, "How Government Systems", s.37. 


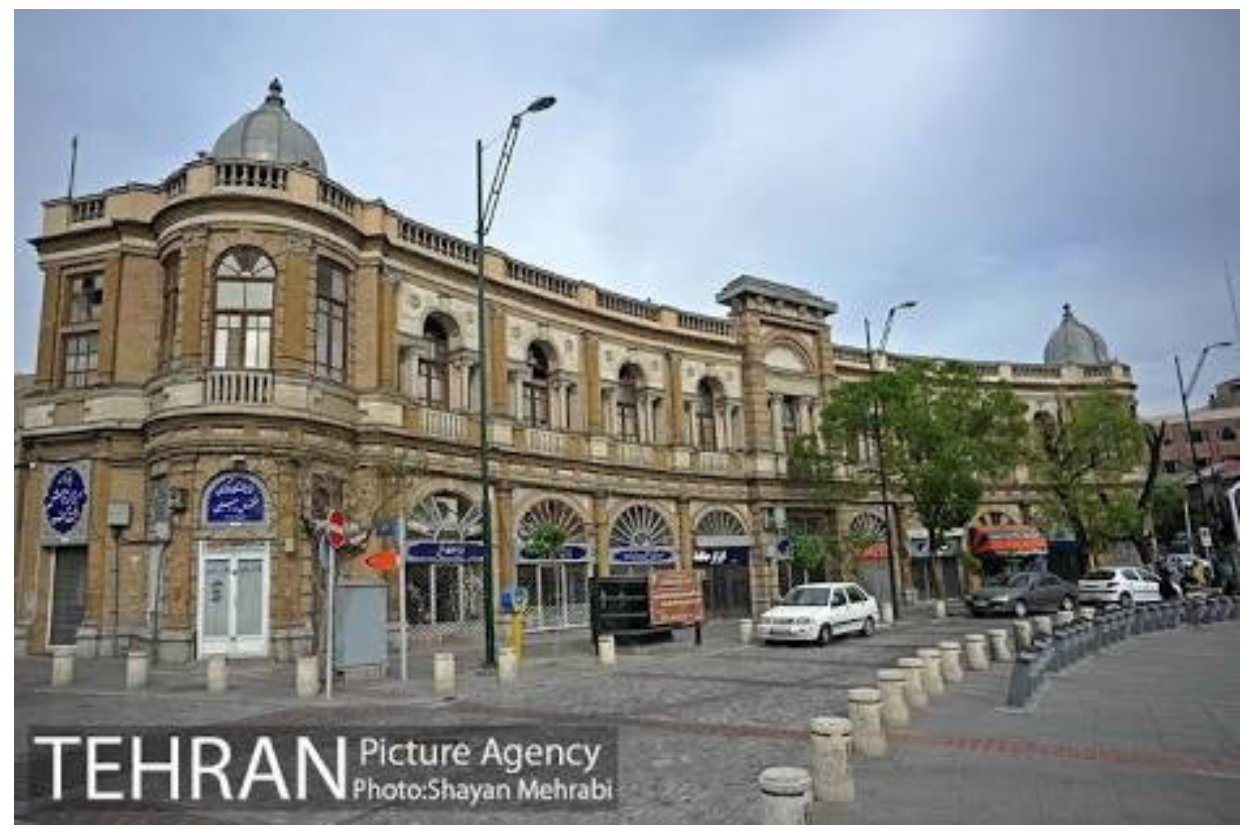

Resim 16. Hasanabad Neydani, Tahran(1930)

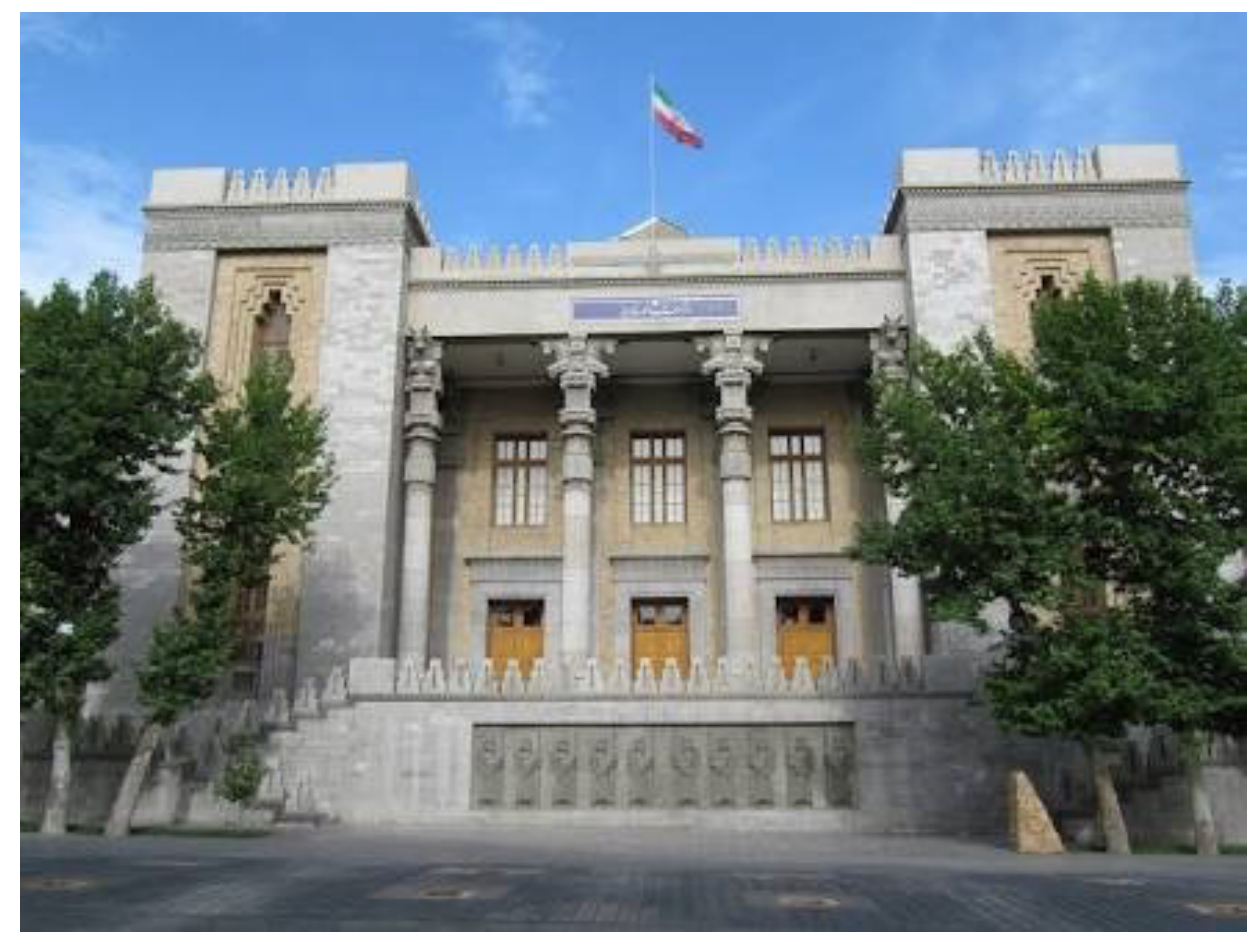

Resim 17. Dış İşleri Bakanlı̆̆ı,(1936)

İslam Sonrası Mimariye Bağlı Kalan Milliyetçi Mimari: İlk Pehlevi döneminde İran'da inşa edilen birtakım binalar geleneksel mimariye ve İslam altyapısına dayanıyordu. Bu yapılar iki tür olarak değerlendirilir: Birincisi, daha önce geleneksel olarak işlev gören binalar ve genelde bazı kamu binaları, camiler, düşünce okulları, ibadet yerleri ve bazen evler ve merkezi hükümet otoritesinin inşaatı ve ikincisi, bu binaların modern yaşamın yeni ihtiyaçlarına ve kalıplarına göre tanımlanması. Bu 
binalarda, farklı mimarlar İran mimarisinin milli kimliğini, İslam'dan sonra mimarinin unsurlarını ve süslemelerini koruyarak ve bazen bunları İslam öncesi mimarinin özellikleri ile birleştirerek, açıllamaya çalıştılar. ${ }^{26}$

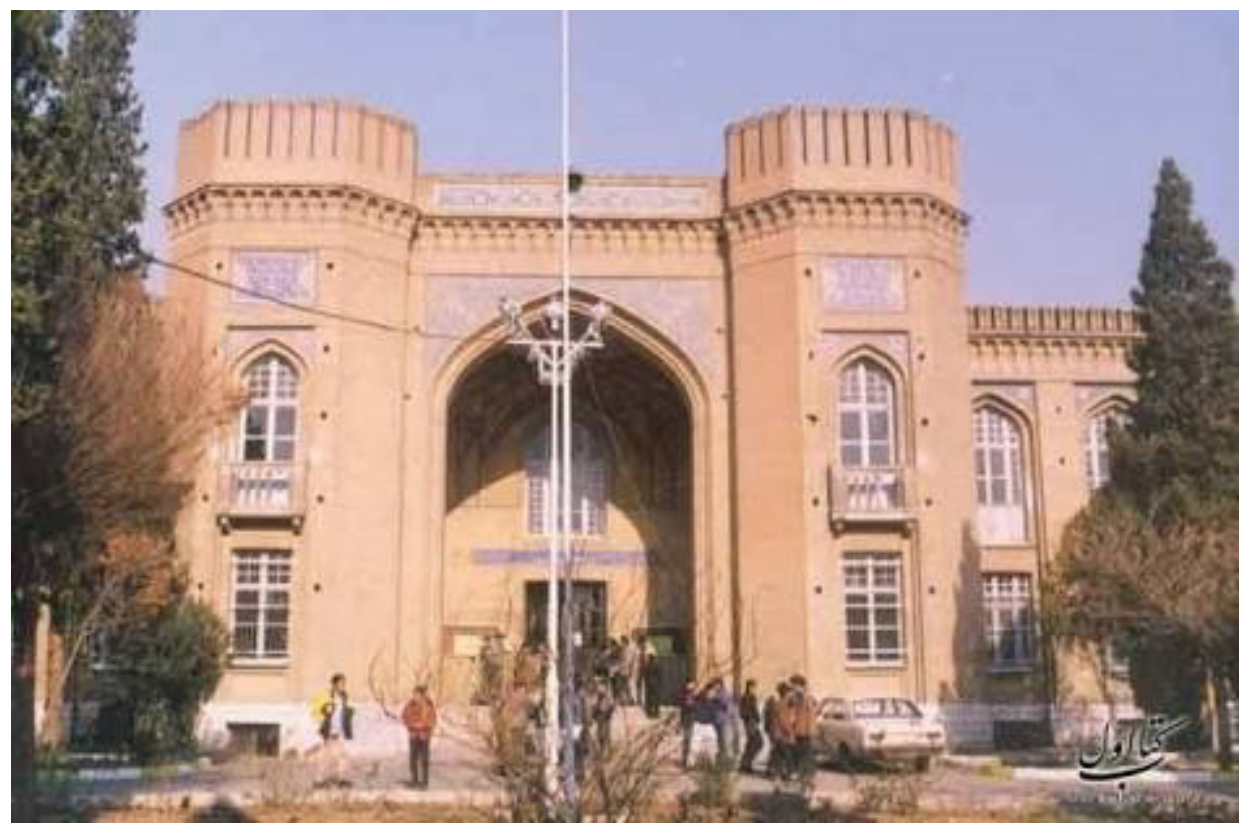

Resim 18. Amerikalılar Koleji, Tehran, (1925)

İslam Öncesi Mimariye Eğilimli Milliyetçi Mimari: On sekizinci ve on dokuzuncu yüzyıl İslamiyet öncesi mimarisine sahip milliyetçi mimarisi Avrupa ve Amerika Birleşik Devletleri’nde arkeolojik ilgi uyandıran müzelerin kurulmasıyla mimarinin oluşumunda derin bir etkisi olup neo-klasik ve Neo-Gotik gibi yeni tarzlar ortaya çıtı. İran'da, Amerikalı Arthur Pope ve Fransız Andre Godard gibi bilimsel araştırmacıların Pehlavỉnin geçmiş mimarisinin tespiti ve araştırılmasında ciddi şekilde faaliyet gösterdiler. İran'da eski İran sanatının tanıtılması ve 1925 yılında Ulusal Anıtlar Derneği kurulması yaklaşımı ile önemli kongrenin oluşması, ülkedeki arkeolojinin gelişimine neden olan faktörlerdi.

Böylelikle çağdaş modern mimarinin Batıdaki etkilerinden ve etkisinden dolayı İlk Pehlevi'nin 20 yıllık döneminde İran mimarisi, aynı anda birkaç farklı mimari formun ortaya çıkışı ve oluşumunun temelini oluşturuyordu:

\section{Modern mimari}

2. Geleneksel mimari

3. Arkeolojik mimari

4. Neoklasik Batı Mimarisi

Bu uygulamalar İran mimarisine paralel gerçekleştiğinden, yukarıdaki yöntemlerin 
bazılarında eklektik yapılar oluşturdu. ${ }^{27}$

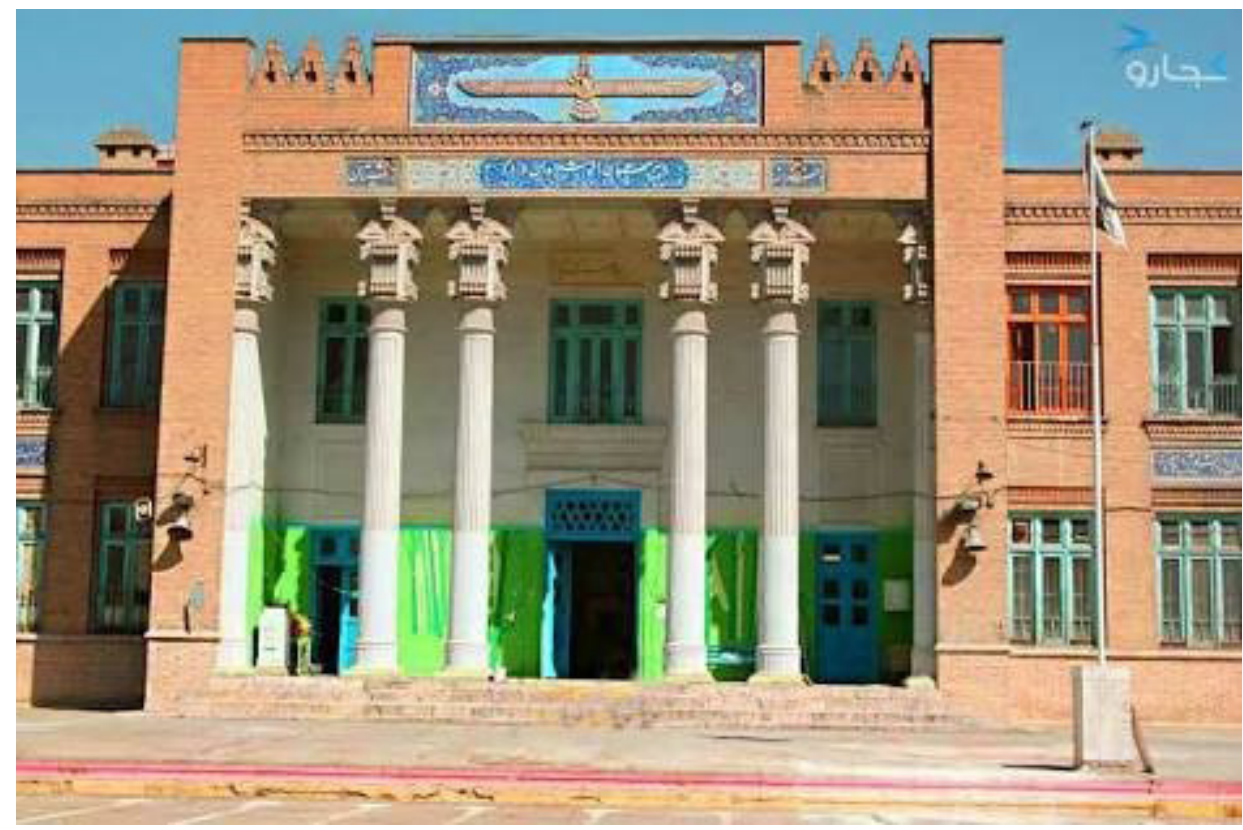

Resim 19. Enuşirvan Medresesi, (1930)

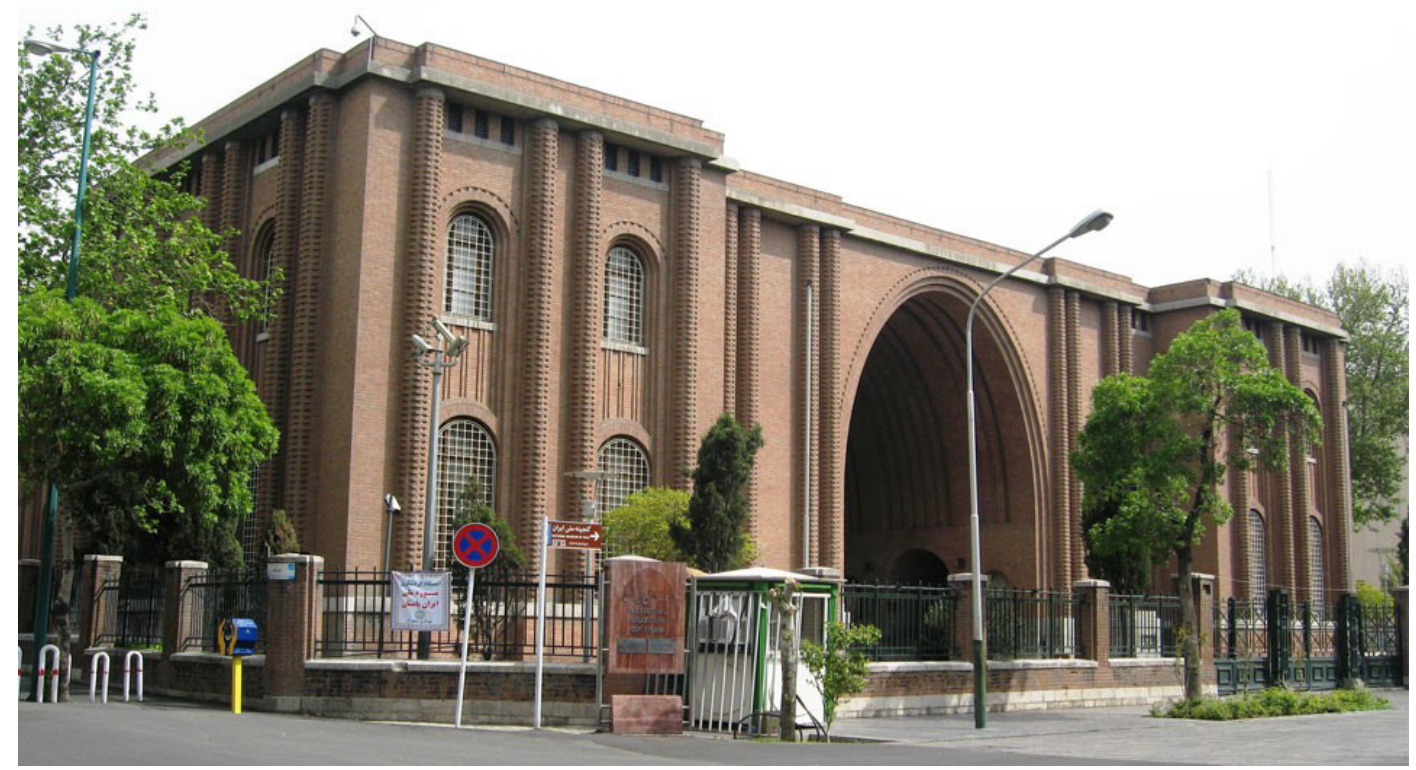

Resim 20. Eski İran Müzesi, (1934)

\section{Sonuç}

1920’lerin başından bu yana, İran ve Türkiye yönetim biçiminde ve insanların yaşadığ yolda köklü değişiklikler isteyen hükümetleri tecrübe ettiler. Bir taraftan, bu hükümetler Batı’nın ilerlemelerini ve medeniyetlerini gördüler ve öte yandan geçmişin görkemli medeniyetlerini tekrar okumak ve ülkelerinin tarihsel gücünü tanımla-

27 Soheili ve Diba, “How Government Systems”, s.39. 
mak zorundaydılar. Dini yönelimler, tarihsel ve eski yönlerin keşfi, Batı ülkelerinin etkisi, Batı'daki seçkinlerin ve entelektüellerin etkileri ve iki ülkenin yöneticilerinin etkileşimi gibi unsurlardan etkilenen her ülkenin mevcut milliyetçi platformlarını göz önüne alarak ulusal kimliğin tanımlanması projesi, ulusalcı hareketlerin ortaya çıkmasına yol açtı.

Çağdaş Türk mimarisi tarihi, modernitenin akışı ile milliyetçilik eğilimleri arasındaki dramatik bir hareketten de etkilenmiştir. Bu hareket, bahsedilen yaklaşımlardan birinin mükemmelliğine yol açtı; böylece, on yılın her döneminde 1960'larda milliyetçilikte ve modernlikte bir titreşimin olduğu söylenebilir. Daha ayrıntılı olarak belirtildiği üzere, 1923’ten 1928'e ve 1938-1950 yılları arasındaki iki tarihsel dönemde baştaki hükümetin politikalarından etkilenen milli mimari projeleri sunuldu. Yukarıda sözü edilen iki dönemin her birinin projesinin ana özelliği, ikinci dönemde Anadoludaki bölgesel mimarinin özgünlügüüne ve modern Batı mimarisinin özelliklerine ek olarak dikkat çeken Osmanlı mimarisinin tekrarlanmasıydı.

Mimarlık alanında, üç liberal, dini ve antik odaklı eğilim arasında İran'da ilk ve son eğilimler 1925-1941 yılları arasındaki milliyetçi hareketlerin ortaya çıkış kaynakları olarak etkili oldu. Bu grup mimarların İslam öncesi ve sonrası mimari süslemelerden İslam öncesi mimariden ve binaların içinden faydalanırken, modern Batı mimarisi kalıplarının eserlerine uygulanmasına dikkat çekiliyor. Görünen o ki, ilk on yılda dostluk politikası ve Rıza Şah’ın ikinci on yılındaki dini bir yandan yabancı mimarların ve yurtdışında eğitimli mimarların varlığı hüküm sürüp eklektik yaklaşımla İslam öncesi ve sonrası mimarinin unsurları ortaya çıkmıştır.

\section{Kaynakça}

Alkan, Ahmet. “Türkiye’nin Kentleşme Deneyiminden Öğrenmek”. International Conference on Civil Engineering, Architecture \& Urban Management in Iran. Ferdowsi University of Mashad, 2018.

Aytaç, Hatice. "The International Diffusion of Planning Ideas: The Case of Istanbul, Turkey”. Journal of Planning History. 6/2 (2007): 114-121.

Balamir, Aydin. "Modern Türkiyede Mimari ve Yapılşma Kültürünün Kimliği”. Abadi, Mimari ve Kentleşme Dergisi. 38/3 (2003): 20-45.

Banimasoud, Amir. Batı Çă̆daş Mimarisi. Tehran: Honar-e Memari-e Gharb. 2009.

Batur, Afife. A Concise History: Architecture in Turkey throughout the 20th Century. Turkey: The chamber of Architects of Turkey. 2005.

Behnam, Jamshid. Iran'lllar ve Yenilenme Düşüncesi, Tehran: Nashr va Pazhouhesh-e farzan Rouz. 2007. [FARSÇA].

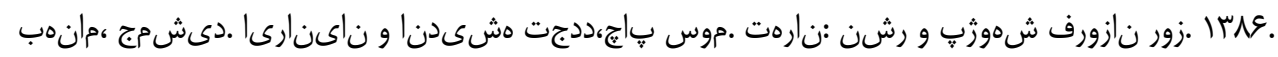

Bozdoğan, Sibel ve Reşat Kasaba. Rethinking Modernity and Identity in Turkey.

University of Washington Press. 1997.

Ghamari, Daryoush. İran'da Milliyetçiliğin Dönüşümü, Tehran: Markaz-e Asnad-e Enghelab-e Eslami, 2001. [FARSÇA].

بالقنا دانسا زكرم تاراشتنا :نارهت .لوا پاج ،نارىا رد مسىلانوىسان لوحت .شوىراد ،ىرمق

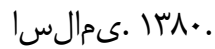


Hasanpour, Naser ve Hosein Soltanzadeh. "Background Factors in Contemporary Architecture Developments of Iran During the Second Pahlavi and Comparative Comparison with Turkey“. Bagh-e Nazar: The scientific journal of Nazar Research Center, for Art. Architecture \& Urbanism. 13/44 (2017): 39-52.

Holod, Renata. Modern Turkish Architecture. University of Pennsylvania. 2005.

Kiani, Mostafa. Birinci Pehlevi Döneminin Mimarisi. Tehran: Moassese Motaleat-e Tarikh-e Moaser-e İran. 2004. [FARSÇA].

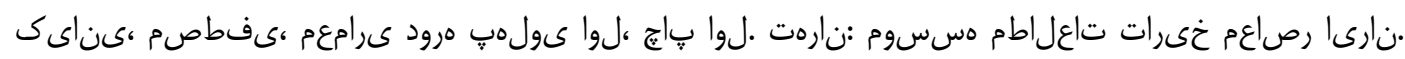
וт人.

Koulaei, Elaheh. İran'da Ulusal Kimliğin Süreci. Tehran: Jahad-e Daneshgahi. 2007. [FARSÇA].

$$
1386 .
$$

Sari Al-Ghalam, Mahmoud. İran Kimliğinde İslam ve Liberalizm Arasındaki Yüzleşme. Tehran: Jahad-e Daneshgahi. 2007. [FARSÇA].

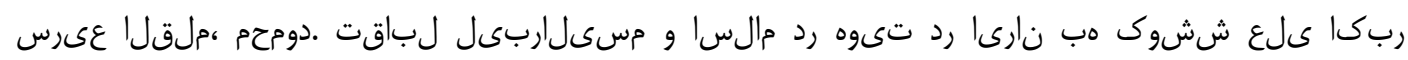

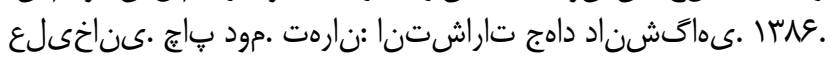

Soheili, Jamaleddin ve Darab Diba. "How Government Systems Have Influenced the Emergence of Nationalist Architectural Movements in Iran and Turkey". Bagh-e Nazar: The scientific journal of Nazar Research Center, for Art. Architecture \& Urbanism. 7/14 (2010): 27-44.

Tekeli, Ilhan. The social context of the development of architecture in turkey, In Modern Turkish Architecture. Pennsylvania: University of Pennsylvania Press. 2005. 
İNSAN\&İNSAN, Y11/Year 6, Sayı/Issue 22, Güz/Fall 2019, 809-830

DOI: https://doi.org/10.29224/insanveinsan.515362

\title{
The Impact of Nationalist Movements on Turkey and Iran Contemporary Architectural Evolution
}

NAVID KHALEGHIMOGHADDAM

\begin{abstract}
This paper firstly investigates social and political platform developed by nationalism in Iran and Turkey between the years 1920-1950 and introduce the main fac-tors in the formation of nationalist ideas. The author examines how formal cooperation between Iran and Turkey governments influences the formation of nationalist movements. Then, research reveals promotions related to the nationalist architectural movements of Turkey and Iran nationalists policies. Therefore, based on the opinion of the critics, paper investigates some architectural buildings of the two countries. Finally, to discuss how the governmental policies affect Iran and Turkey nationalist architectural movements, a comparative study is conducted. Accordingly, Iran and Turkey apply their experience in the formation of a government to demand fundamental changes in people's lifestyle. In this way, factors such as religious ideas, historical aspects, western countries influences, and the interaction of the governments of the two countries cause nationalist movements.
\end{abstract}

Keywords: Government, Nationalist movements, Architecture, Iran, Turkey. 